See discussions, stats, and author profiles for this publication at: https://www.researchgate.net/publication/328555844

\title{
'All you need is brand love': A critical review and comprehensive conceptual framework for brand love
}

Article in Journal of Marketing Management · October 2018

DOI: 10.1080/0267257X.2019.1572025

\section{CITATIONS}

35

3 authors:

Narissara Palusuk

Rennes School of Business

2 PUBLICATIONS 54 CITATIONS

SEE PROFILE

Rajibul Hasan

National University of Ireland, Maynooth

65 PUBLICATIONS 271 CITATIONS

SEE PROFILE

Some of the authors of this publication are also working on these related projects:

COVID 19 Research View project

Project Journal of Business Research Special Issue - Virtual Reality in Marketing View project
Bernadett Koles

IESEG School of Management 32 PUBLICATIONS 370 CITATIONS SEE PROFILE 


\section{'All you need is brand love': a critical review and comprehensive conceptual framework for brand love}

\section{Narissara Palusuk, Bernadett Koles \& Rajibul Hasan}

To cite this article: Narissara Palusuk, Bernadett Koles \& Rajibul Hasan (2019): 'All you need is brand love': a critical review and comprehensive conceptual framework for brand love, Journal of Marketing Management, DOI: 10.1080/0267257X.2019.1572025

To link to this article: https://doi.org/10.1080/0267257X.2019.1572025

Published online: 07 Feb 2019.

Submit your article to this journal $[\pi$

View Crossmark data \lceil 


\title{
'All you need is brand love': a critical review and comprehensive conceptual framework for brand love
}

\author{
Narissara Palusuk, Bernadett Koles (D) and Rajibul Hasan \\ Department of Marketing, Rennes School of Business, Rennes, France
}

\begin{abstract}
Brand love has received increasing attention given its potential to enhance customer engagement, brand advocacy, commitment and loyalty. Despite its relevance, few studies explore brand love per se, and existing conceptualisations remain sporadic and fragmented. The purpose of the current paper is to critically assess available work on brand love, reviewing conceptualisations, measurements and key proximal constructs. Expanding upon and synthesising earlier work and conceptualisations, we develop and propose a comprehensive conceptual framework for brand love that is innovative for the following reasons. In particular, our model takes a developmental rather than a snapshot approach to capture brand love trajectories as a function of their onset and evolution; incorporates key frameworks and as such builds on interpersonal, parasocial and experiential theories; and acknowledges the important role of brand hate. Managerial implications and future research directions are discussed.
\end{abstract}

\section{ARTICLE HISTORY}

Received 1 February 2018

Accepted 25 October 2018

\section{KEYWORDS}

Brand love; consumer-brand relationship; brand love evolution; brand hate; relationship trajectory

\section{Introduction}

Given the ubiquity of consumer choice, organisations recognise that achieving liking and satisfaction is no longer sufficient to retain customer loyalty over time (Jones \& Sasser, 1995). Instead, marketers are encouraged to find ways to make their brands loved by customers (Castaño \& Eugenia Perez, 2014; Rauschnabel, Ahuvia, Ivens, \& Leischnig, 2015; Sallam, 2014; Wallace, Buil, \& Chernatony, 2014). Understanding brand love is relevant given the desirable organisational outcomes like positive word of mouth (WOM) (Batra, Ahuvia \& Bagozzi, 2012), brand loyalty (Carroll \& Ahuvia, 2006), consumer willingness to pay a premium price (Thomson, Maclnnis, \& Park, 2005), forgiveness of brand failures (Bauer, Albrecht, \& Heinrich, 2009), and favourable public display of affection towards the brand (Batra et al., 2012).

In their recent book on brand admiration, Park, Maclnnis, and Eisingerich (2016) highlight that brands present the greatest value to customers when combining enabling, enticing and enriching benefits. According to the authors, 'when brands provide these three types of benefits and empower, gratify, and inspire customers, customers want to establish a long-term relationship with the brand. When a brand

CONTACT Narissara Palusuk narissara.palusuk@rennes-sb.com 0 Rennes School of Business, 2, Rue Robert d'Arbrissel - CS 76522, Rennes Cedex 35065, France

(c) 2019 Westburn Publishers Ltd. 
provides these three benefits, customers come to trust, love, and respect the brand; in short, they admire it' (p. 15). In their model, they envision brand love to derive from those enticing benefits that stimulate the mind and warm the heart, making customers feel gratified, engaged, entertained and warm-hearted, which in turn collectively induce brand love.

Despite its clear advantages, research on brand love is scarce, and as a concept insufficiently developed. For instance, difficulties arise when distinguishing brand love from other proximal constructs such as brand liking (Langner, Schmidt, \& Fischer, 2015; Sternberg, 1986), brand passion (Carroll \& Ahuvia, 2006) or brand attachment (Park, Maclnnis, \& Priester, 2006; Park, Maclnnis, Priester, Eisingerich, \& lacobucci, 2010). Scholars are also divided by the literature they use to study brand love. While some academics apply the framework of interpersonal love theory (Albert, Merunka, \& ValetteFlorence, 2008; Albert \& Valette-Florence, 2010; Thomson et al., 2005; Whang, Allen, Zhang, Sahoury, Kahn, \& Frances Luce, 2004), others advocate one-way (Bergkvist \& Bech-Larsen, 2010) or parasocial (Fetscherin, 2014) perspectives. As a third alternative, the grounded theory approach has been proposed to study brand love, emphasising the importance of the phenomenological experience in consumer-brand relationships (Batra et al., 2012). Finally, there is increasing research on brand hate (Grégoire, Tripp, \& Legoux, 2009; Zarantonello, Romani, Grappi, \& Bagozzi, 2016), brand betrayal (Grégoire \& Fisher, 2008; Grégoire et al., 2009; Reimann, Maclnnis, Folkes, Uhalde, \& Pol, 2018) and brand aversion (Park, Eisingerich, \& Park, 2013), yet our understanding of how they relate to brand love, and importantly how they evolve over time remains limited.

In light of these shortcomings, the purpose of the present paper is to explore brand love, building on as well as reaching beyond the existing literature. First, we begin the paper by elaborating upon the relevance of brand love for marketers, highlighting key affordances. Second, we provide a comprehensive review of existing conceptualisations and empirical work in order to capture the current state of brand love research. Third, we provide a theoretical framework that introduces brand love trajectories as a function of their onset and evolution, merges interpersonal, parasocial and experiential lenses, and incorporates associations with brand hate. Finally, we conclude the paper by offering practical takeaways and highlighting future research directions.

\section{What is brand love and why it matters}

The role of love in consumer-object and consumer-brand relationships has been the focus of much inquiry (Ahuvia, 2005; Albert \& Merunka, 2013; Albert et al., 2008; Batra et al., 2012; Bergkvist \& Bech-Larsen, 2010; Carroll \& Ahuvia, 2006; Fournier, 1998). Important similarities have been established between the emotional feelings that people hold towards loved ones and those that consumers hold towards objects and material goods (Albert \& Valette-Florence, 2010; Shimp \& Madden, 1988; Whang et al., 2004). This tendency in the branding context has been referred to as brand love; which Carroll and Ahuvia (2006) define as 'the degree of passionate emotional attachment a satisfied consumer has for a particular trade name' (p. 81).

Brand love has been associated with a number of organisational benefits (Rossiter, 2012). Among the advantageous brand outcomes, brand loyalty and positive WOM are the two most frequently cited. Brand loyalty refers to a commitment on behalf of the 
consumer that captures 'an enduring desire to maintain a valued relationship' (Moorman, Zaltman, \& Deshpande, 1992, p. 316) with a certain brand (Assael, 1987). It has been demonstrated that the impact of brand love on brand loyalty often occurs through the mediating role of enhanced consumer attitude, which results in loyalty and higher willingness to pay a premium price (Park et al., 2006). In addition, devoted customers can become dedicated spokespersons and brand representatives (Fullerton, 2005), and engage in positive WOM (Batra et al., 2012; Carroll \& Ahuvia, 2006; Far \& Dinani, 2015; Ismail \& Spinelli, 2012; Karjaluoto, Munnukka, \& Kiuru, 2016; Wallace, Buil \& Chernatony, 2014)). Another related brand affordance concerns brand advocacy (Batra et al., 2012), which, according to Wallace et al. (2014), includes talking favourably about the brand, displaying an openness to try new products, and being willing to resist negative information or occasionally accept potential wrongdoings from a brand. Fournier (1998) confirmed that 'feelings of love' (pp. 364) may give consumers an inflated positive perception about the brand, which in turn may lead to brand advocacy behaviours, and as such not only help the brand by providing positive information, but also by reducing the potentially harmful implications associated with negative information (Du, Bhattacharya, \& Sen, 2007).

Other positive outcomes include higher engagement and more positive brand associations (Kang, 2015), which in turn can predict continuance, affective brand commitment (Albert \& Valette-Florence, 2010) and willingness to pay a premium price (Albert \& Merunka, 2013). Active engagement occurs 'when customers are willing to invest time, energy, money, or other resources in the brand beyond those expanded during purchase or consumption' (Bergkvist \& Bech-Larsen, 2010, p. 507). Similarly, Ahuvia (2005) found loved items to be 'objects and activities that demanded a sizable investment of time and energy' (p. 182), concluding that consumers who love a brand are more likely to maintain their engagement over time. Customer engagement is conceptually different from involvement in that involvement often precedes engagement (Vivek, 2009). Active engagement can also be distinguished from WOM in that engagement may capture a wide range of product categories (Bergkvist \& Bech-Larsen, 2010), while WOM is primarily prevalent in the case of self-relevant products (Chung \& Darke, 2006).

\section{Theoretical positioning}

One of the difficulties in understanding brand love concerns the diversity of available conceptualisations characterising contemporary scholarship. The majority of scholarly work situates the concept of brand love within the greater theoretical orbit of interpersonal relationships (Fetscherin, 2014; Hess, Story, \& Danes, 2011). Within the general love literature, several theories have been proposed that include elaborate and multidimensional approaches (Masuda, 2003). Amongst the pioneers, Rubin (1970) was the first to measure love using a psychological scale, giving rise to a systematic differentiation between romantic love characterised by love and liking versus platonic friendship characterised by liking alone. The colour wheel love theory put forth by Lee (1977) distinguishes between two of the most rudimentary love styles of erotic love and companionate love, extending earlier conceptualisations. A framework that has been applied extensively to consumer research is the Triangular Theory of Love proposed by Sternberg (1986) encompassing three primary dimensions. Intimacy refers to relationship 
closeness and connectivity and is ultimately tied to overall happiness; passion entails physical attraction and psychological arousal, and in turn is linked with romance, selfesteem and self-actualisation; and decision/commitment is the dimension that captures a cognitive perception of love with a short-term (i.e. decision) as well as a long-term (i.e. commitment) orientation. On the basis of these three building blocks, Sternberg (1986) proposed a total of eight different types of interpersonal love, depending on the presence or absence of the three components.

In favour of applying interpersonal love theories to studying brand love, research shows that individuals often employ interpersonal relationship norms as guides when building relationships with brands (Aggarwal, 2004). For instance, in their research exploring the relationship between male motorcyclists and their bikes adopting the colour wheel love theory (Lee, 1977), Whang et al. (2004) found that bikers defined their relationships with their bikes using terminology that was similar to those characterising interpersonal relationships, describing their experience as passionate, possessive and selfless in nature. In their definition of brand love, Carroll and Ahuvia (2006) emphasise two key elements: emotional attachment and passion. Emotional attachment refers to a strong and specific bond and close psychological proximity between a person and a brand. Passion often viewed as a critical component of emotional attachment (Thomson et al., 2005), refers to consumer's desire for a brand that entails high arousal emotions (Batra et al., 2012), separation anxiety (Albert \& Valette-Florence, 2010), and a general sense of pleasure associated with brand ownership (Albert, Merunka, \& Valette-Florence, 2009). Ahuvia (2005) proposed a brand love prototype that captured passionate feelings, attachment, positive emotions, positive brand evaluation and open declarations of love.

Not everyone considers interpersonal love theory suitable to explain consumer-brand relationships. According to Langner et al. (2015), for instance, rational considerations and benefits are more prevalent drivers of brand love than of interpersonal love, and hence they caution against the direct application of interpersonal love theory to brand love conceptualisations. Instead, some scholars advocate one-way or parasocial types of relationships to study brand love. The term parasocial relationship was coined by Perse and Rubin (1989) and was developed on the basis of the term parasocial interaction (Horton \& Richard, 1956). Parasocial relationships entail a single or one-sided form of relationship in which one party holds unreciprocated emotions towards the other party in a relationship dyad (Fetscherin, 2014). Such relationships can manifest themselves in feelings of friendship or intimacy that individuals hold in relation to a famous person or media celebrity (Cohen, 1997; Currás-Pérez, Ruiz-Mafé, \& Sanz-Blas, 2011; Schmid \& Klimmt, 2011). Applying this concept to brands would suggest that consumers establish a unidirectional relationship with brands, while brands - similarly to celebrities - would not be expected to reciprocate the relationship. This fits with the notion of brand anthropomorphism, which posits that consumers espouse brands with human characteristics (Levy, 1985) or brand personalities (Aaker, 1997). Additional supporting evidence comes from the field of cognitive psychology, suggesting that brand versus interpersonal relationships are processed separately and engage different parts of the brain (Yoon, Gutchess, Feinberg, \& Polk, 2006).

To complement the literature with a third theoretical lens, Batra et al. (2012) proposed a grounded theory approach to studying brand love; one that is based on how consumers actually experience brand love on a phenomenological level. Using their own results, the 
authors conclude that while consumers often reference brand love along the lines of interpersonal love, they regard interpersonal love to be more meaningful, to capture a strong element of altruistic concern for the beloved, and to entail reciprocity; the latter two features are absent in the brand love context. Batra et al. (2012) encourage scholars to widen their scope of analysis to move beyond the narrow lens offered by interpersonal love theories, particularly when considering scale development initiatives. Fournier (1998)'s work provides additional insights in favour of experience-based perspectives. Although the author does not discuss brand love per se, in her framework she proposes an elaborate typology for consumer-brand relationships, with particular attention to relationship quality and its effects on stability. Relationship quality is approximated by a combination of love-based and experience-based dimensions, including love/passion, intimacy, interdependence, self-connection, commitment and brand partner quality.

\section{Empirical research and conceptualisations}

In order to better understand the current state of scholarly work focusing on this complex phenomenon, in the current section we review existing empirical research and conceptual development of brand love. Here we concentrate on those studies that centre on the concept of brand love, as opposed to using it as a predictor or an outcome variable. An extensive search capturing the past 15 years of research on brand love was undertaken employing frequently used academic databases (i.e. EBSCO, Google Scholar, and JSTOR). The resulting set of studies $(n=10)$ is presented in Table 1 , in chronological order. In addition to highlighting the objective, methodological orientations and primary contributions of each study, we also mention the theoretical framework in which the respective authors positioned their work. This latter component will be important in the subsequent development of our conceptual model.

The list of studies reveals that certain methodological approaches and sampling considerations (i.e. surveys with US or Western-European groups) were most prominent in the pursuit of brand love, with a few studies embracing a more exploratory approach and employing interviews and mixed-methods designs (Albert et al., 2009; Batra et al., 2012; Langner et al., 2015). Regarding measurement, various scales emerged that vary in their

dimensionality and length. Some conceptualisations approach brand love as a unidimensional construct (Carroll \& Ahuvia, 2006), while most other scales view brand love as a multi-dimensional phenomenon encompassing a variety of key elements. Furthermore, existing scales incorporate anywhere between 1 and 11 dimensions (Batra et al., 2012). The most elaborate scale comes from Batra et al. (2012) with 56 items along seven core dimensions, aiming to achieve a deep understanding of consumer experience. The dimensions include self-brand integration, passion-driven behaviours, positive emotional connection, long-term relationship, positive overall attitude valence, attitude strength and anticipated separation distress. Given the large number of items, the authors recognise that this scale was too long to be useful in scholarly work. More recently, Bagozzi et al. (2017) developed three more concise scales, including a multi-factor brand love scale comprising 26 items; a single-factor scale comprising 13 items; and a short scale comprising 6 items. Another scale building on consumer experience has been proposed by Zarantonello, Formisano et al. (2016), capturing fantasies and thoughts, attachment, self-expression, pleasure and identification. The most elaborate scale situated within 


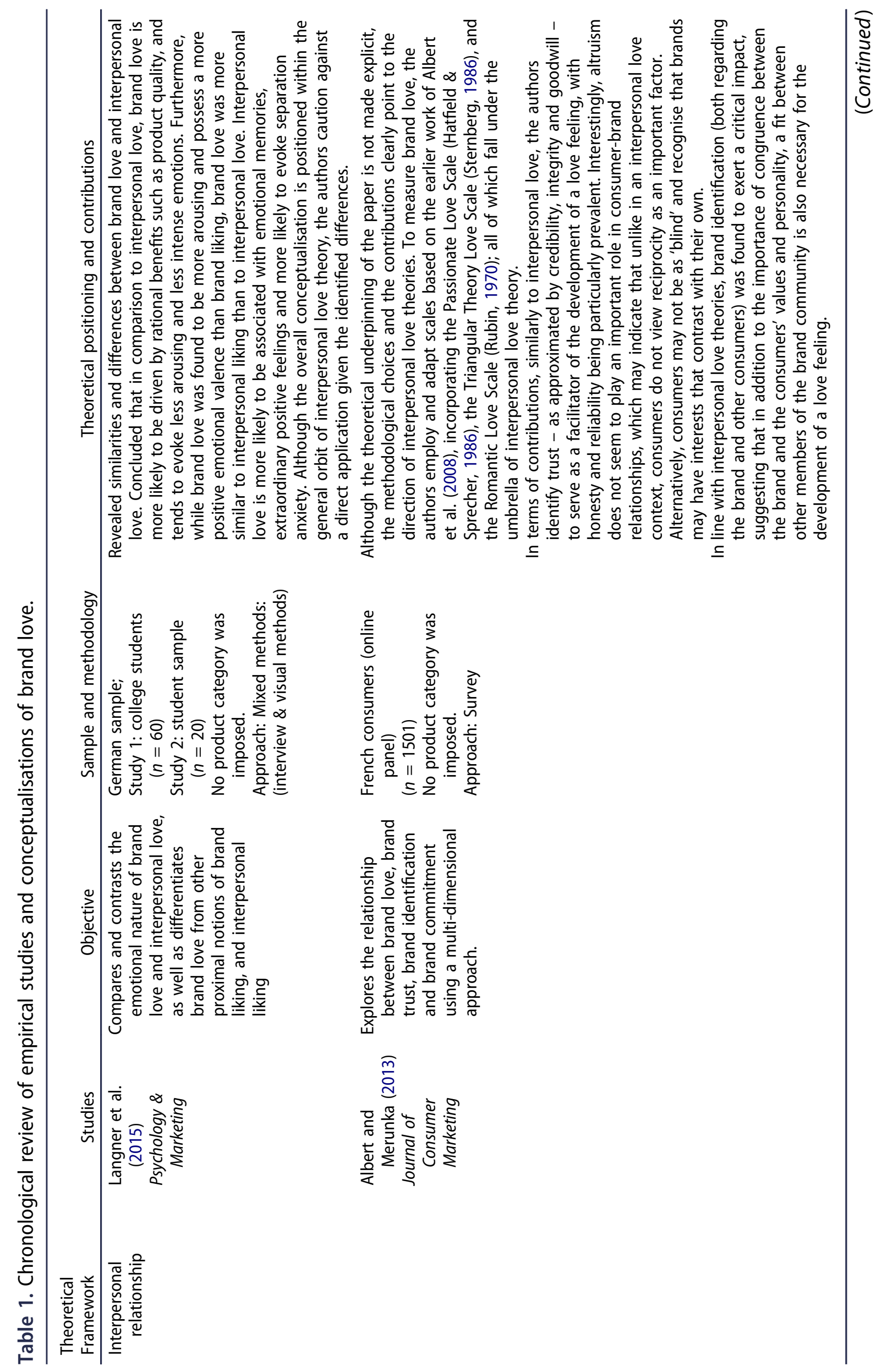




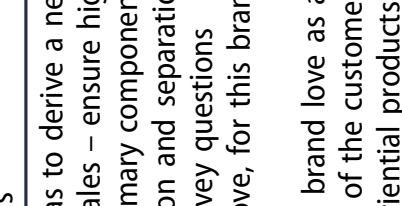

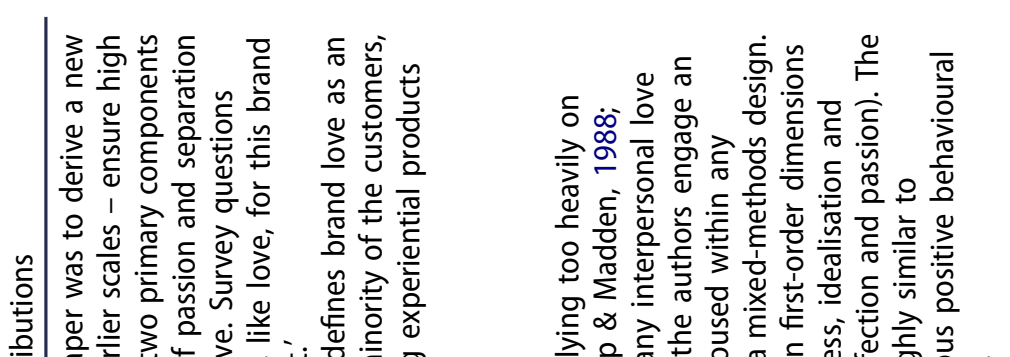

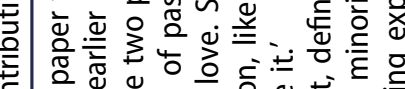

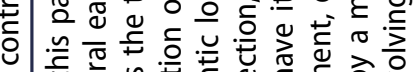

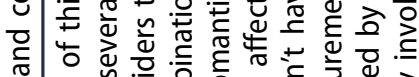

宁

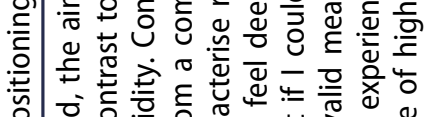

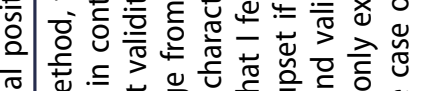

ত⿹

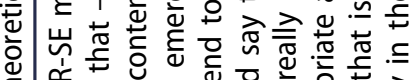

$\stackrel{\Xi}{\risingdotseq}$

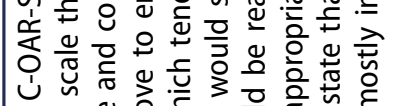

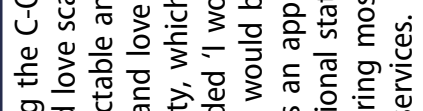

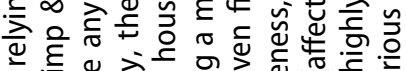

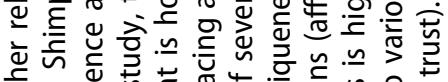

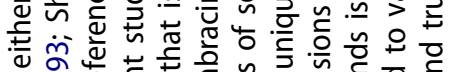

उ人ิ

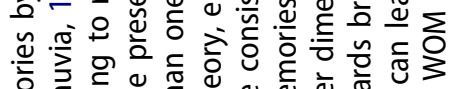

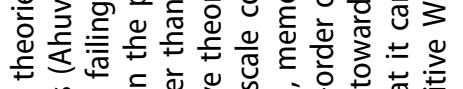

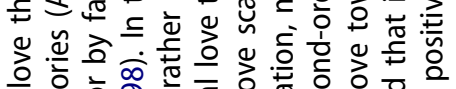

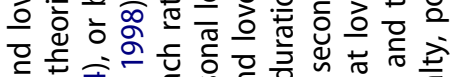

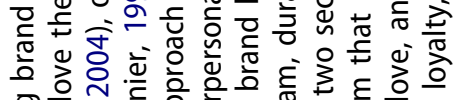

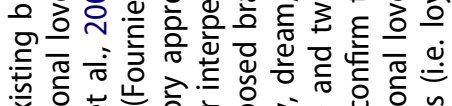

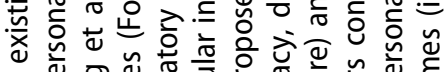

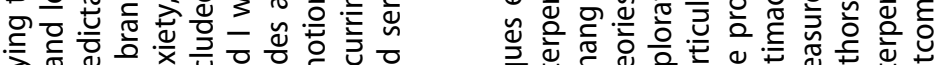

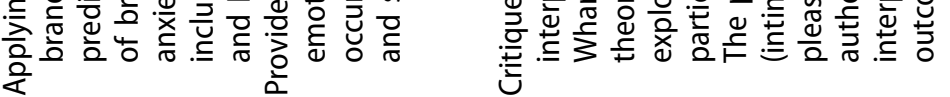

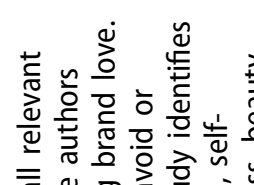

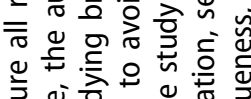

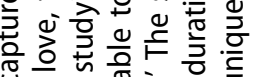

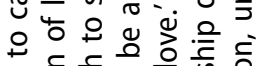

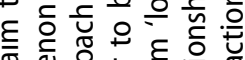

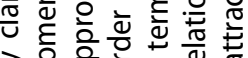

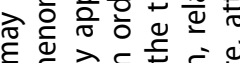

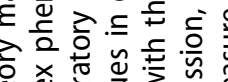

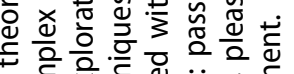

\&

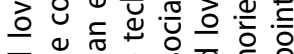
তั 墕

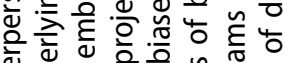

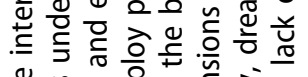

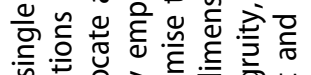

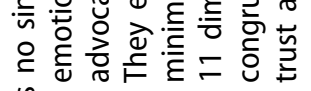

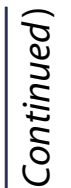

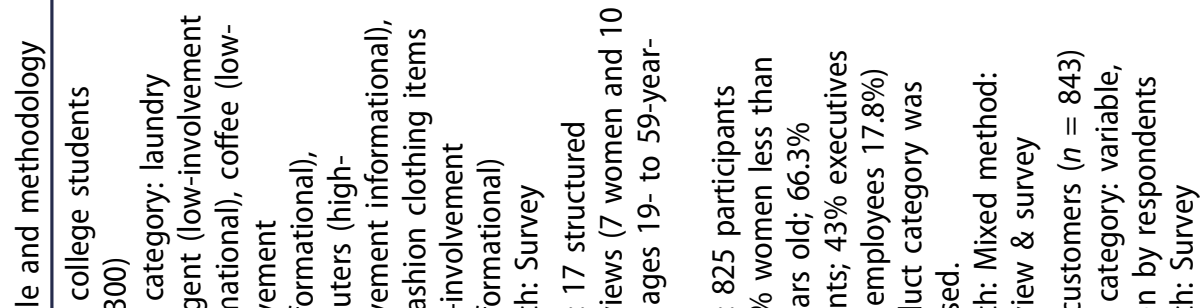

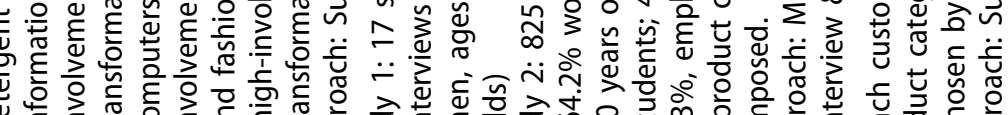

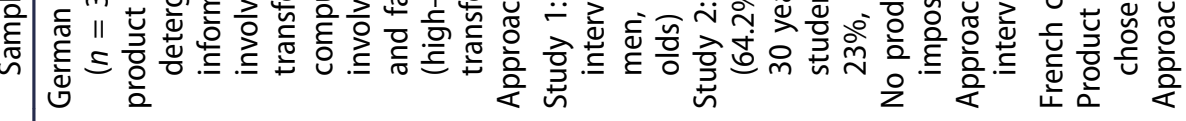

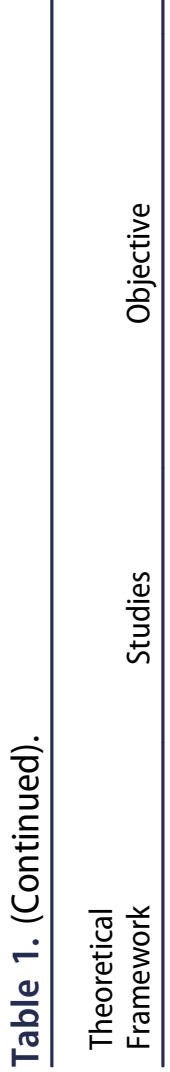

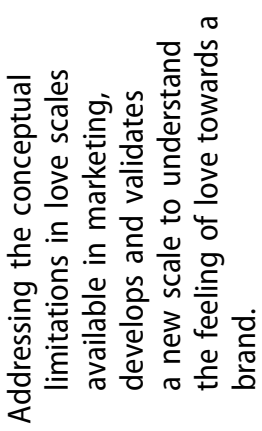

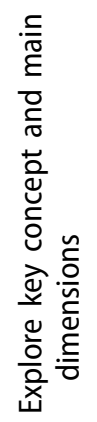

ஓ્d

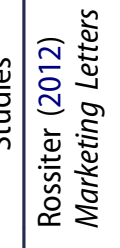

$\dot{\sigma} \cdot \leq \bar{\varpi} s$

屯 气 ॐ

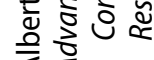

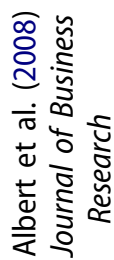




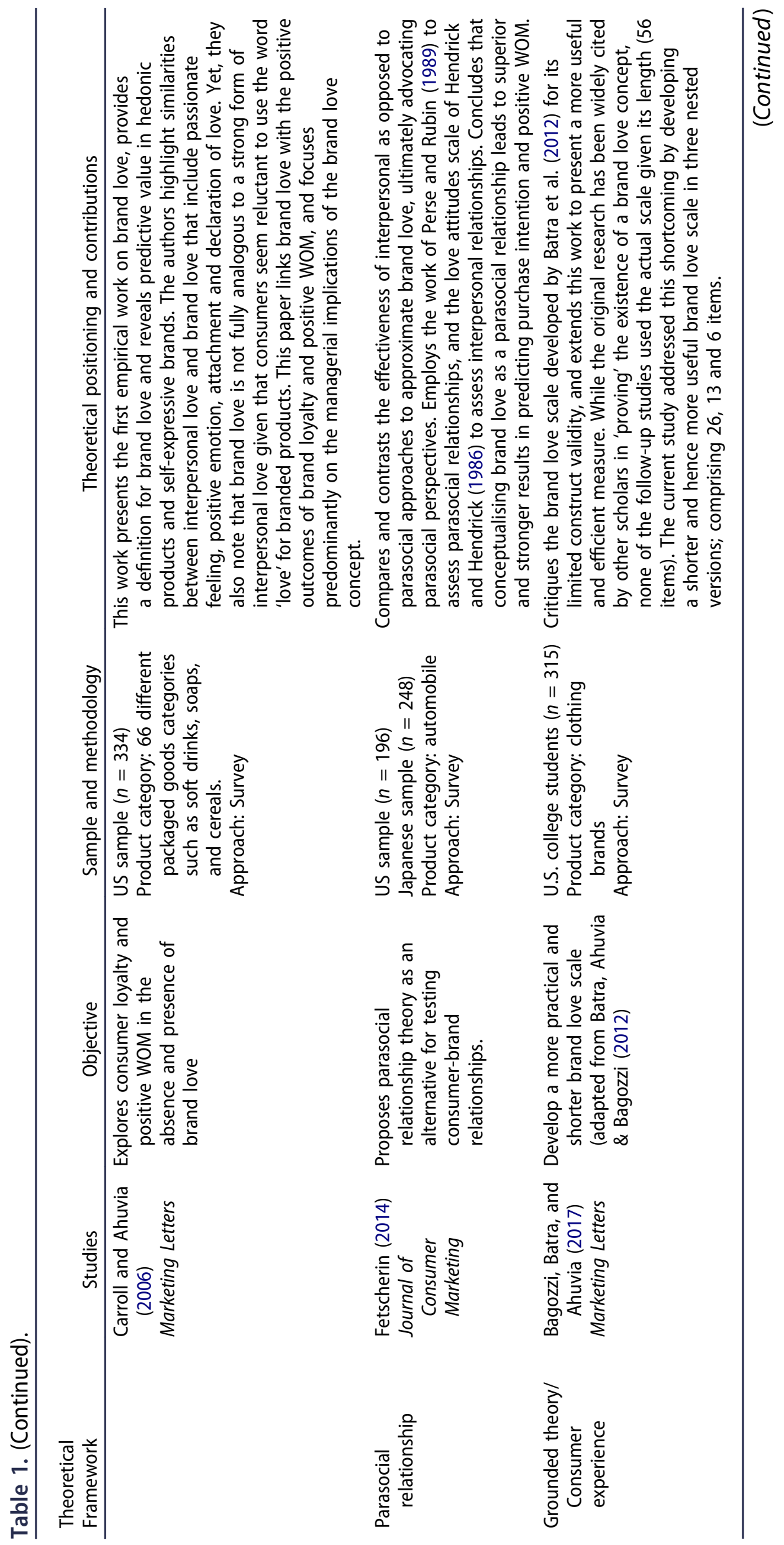




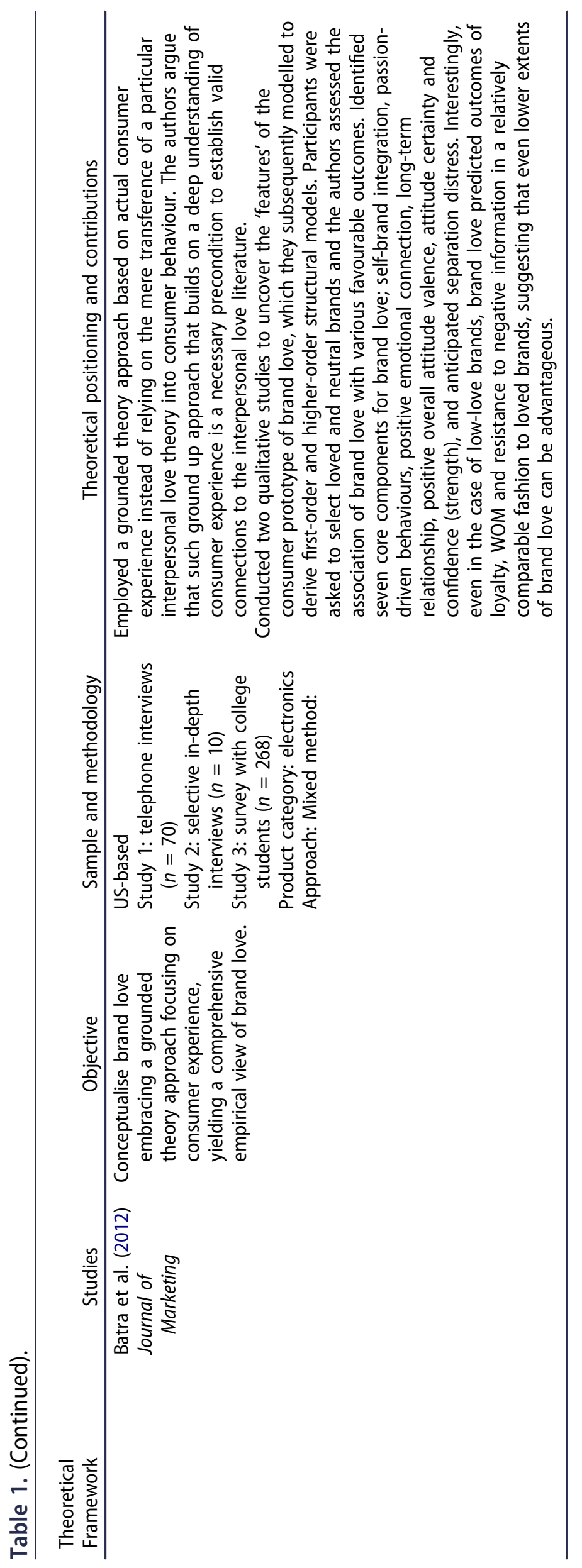


interpersonal love theories comes from Albert and Merunka (2013) incorporating intimacy, dreams, pleasure, memories, unicity, affection and passion. Table A1 (Appendix) provides a complete list of existing scales along with reliabilities (when available). A few additional studies adapting existing measures to fit their purposes exist (Huber, Meyer, \& Schmid, 2015; Long-Tolbert \& Gammoh, 2012; Vlachos \& Vrechopoulos, 2012), but given that they maintained the core elements of previously validated scales as opposed to developing new ones, they are not listed separately.

From a conceptual standpoint, the information in Table 1 demonstrates that the vast majority of existing brand love studies embraces an interpersonal love relationship orientation, with substantially fewer studies that rely on one-way parasocial or experience-based perspectives. Upon closer inspection of the theoretical positioning and contributions, additional insights can be obtained that characterise the current state of research, and in turn, shed light on the apparent inconsistencies in positioning and defining the brand love concept. First, while scholars recognise its conceptual complexity, few actually provide a definition of brand love in their own work. Instead of conceptualisations, the focus tends to remain on identifying key antecedents and outcomes in pursuing practice-oriented managerial implications. Second, scholars embracing interpersonal love theories are not homogeneous in their views. While many identify similarities, they also posit that in comparison to interpersonal love, brand love tends to evoke less arousal and less intense emotions; entail more rational elements (Langner et al., 2015); trigger lower expectations in terms of goodwill and altruism (Albert \& Merunka, 2013); and thus generally cannot be viewed as fully analogous to interpersonal love (Albert et al., 2009, 2008; Carroll \& Ahuvia, 2006).

Finally, the current research positions the brand love concept as a rather static phenomenon, which in turn limits our understanding of its evolution and developmental trajectories over time. To date, there is one single study by Langner, Bruns, Fischer, and Rossiter (2016) that addresses brand love from a developmental perspective. Additional research along these lines would be useful for various reasons. On the one hand, knowing how brand love evolves over time would enable the identification of factors that help as opposed to hinder the positive evolution of consumer love towards a given brand. On the other hand, the vast majority of the brand love literature concerns positive consumer-brand relationships, leaving the exploration of the relationship between brand love and brand hate insufficiently developed.

Brand hate is the most intense negative emotion that consumers may feel towards brands (Zarantonello, Romani et al., 2016). Another related notion is brand betrayal, which may predict the desire for revenge and more generally negative WOM (Grégoire et al., 2009). Grégoire and Fisher (2008) indicated that the concept of betrayal is distinct from other negative emotions such as anger and dissatisfaction. Moreover, while betrayal is based on a reference to relationship norms, anger and dissatisfaction may occur without any relational circumstance. Importantly, this sensation is not necessarily maintained over time as long as a suitable recovery system is provided. Finally, brand aversion refers to a perceived threat associated with a self-contraction when a consumer becomes opposed to and feels distant from the brand (Park et al., 2013). Interestingly, research demonstrates that brand hate is not necessarily on the opposite end of the continuum from brand love, but instead this relationship represents complex and cyclical dynamics where love may turn into hate over time (Zarantonello, Romani 
et al., 2016). Similarly, the brand attachment-aversion relationship captures a cyclical dynamic that further accentuates the importance of developmental approaches.

In response to these gaps and inconsistencies in the brand love literature, and integrating prior research, the purpose of the following section is to develop a conceptual model for brand love, incorporating different relationship trajectories.

\section{Brand love - merging theoretical lenses}

Building on the interpersonal love literature, Sangrador and Yela (2000) distinguish between situations when people fall in love speedily at first sight as opposed to when their love evolves in a more gradual fashion. Riela, Rodriguez, Aron, $\mathrm{Xu}$, and Acevedo (2010) add that love at first site scenarios place greater emphasis on physical appearance, and that the speed of love is dramatically impacted by dispositional traits such as human personality and mate preferences. These ideas would be interesting to explore within the auspices of brand love, with the aim of identifying potential synergies.

A particularly interesting analogy can be applied based on the ideas of lyengar (2011), comparing the success of arranged marriages and love marriages in a longitudinal fashion. Building on the work of Gupta and Singh (1982), lyengar suggests that while these two types of arrangements differ from one another at a given point of time, interesting patterns can be identified when explored over a 10-year period. More specifically, while in comparison to arranged marriages, love marriages tend to score significantly higher on the Rubin love scale at the initial point of comparison taking place after the first year of marriage, arranged marriages significantly outperform love marriages at the 10-year comparison point. This body of work indicates that while love marriages may start out hot yet cool down over time, arranged marriages may start out cooler but may increase over time. In this sense, arranged marriages may reveal a positive tendency for long-term improvement, while love marriages may entail a negative tendency represented by a downward pattern, which in turn seems to provide a good approximation for how different love relationship trajectories are likely to develop over time. Applying these ideas to the brand love concept would be advantageous, as they would help advance brand love conceptualisations to a higher and more complex level, and in turn enable a more comprehensive understanding of how consumers establish and experience love towards brands over time. Such an inclusive approach is also relevant in deciphering how brand love emerges and how it may be induced by firms.

Synthesising and expanding upon available literature and theoretical foundations, Figure 1 presents our conceptual framework that on the one hand merges the three primary lenses, and on the other hand incorporates a developmental orientation via establishing different brand love trajectories, as approximated by the analogies of love marriage, experience-based relationships and arranged marriage. In order to elaborate upon each relationship type, we employ four important theoretical frameworks. First, we establish links between our framework and existing dominant typologies that either explore consumers' love (Sternberg, 1986) or the form and strength of their relationships towards brands (Fournier, 1998; Thomson et al., 2005).

Second, we build on the work of Sampedro (2017) and Reimann, Castaño, Zaichkowsky, and Bechara (2012), who established and applied a range of consumer-brand relationship types as a function of the extent of congruence between the consumer's identity and the 


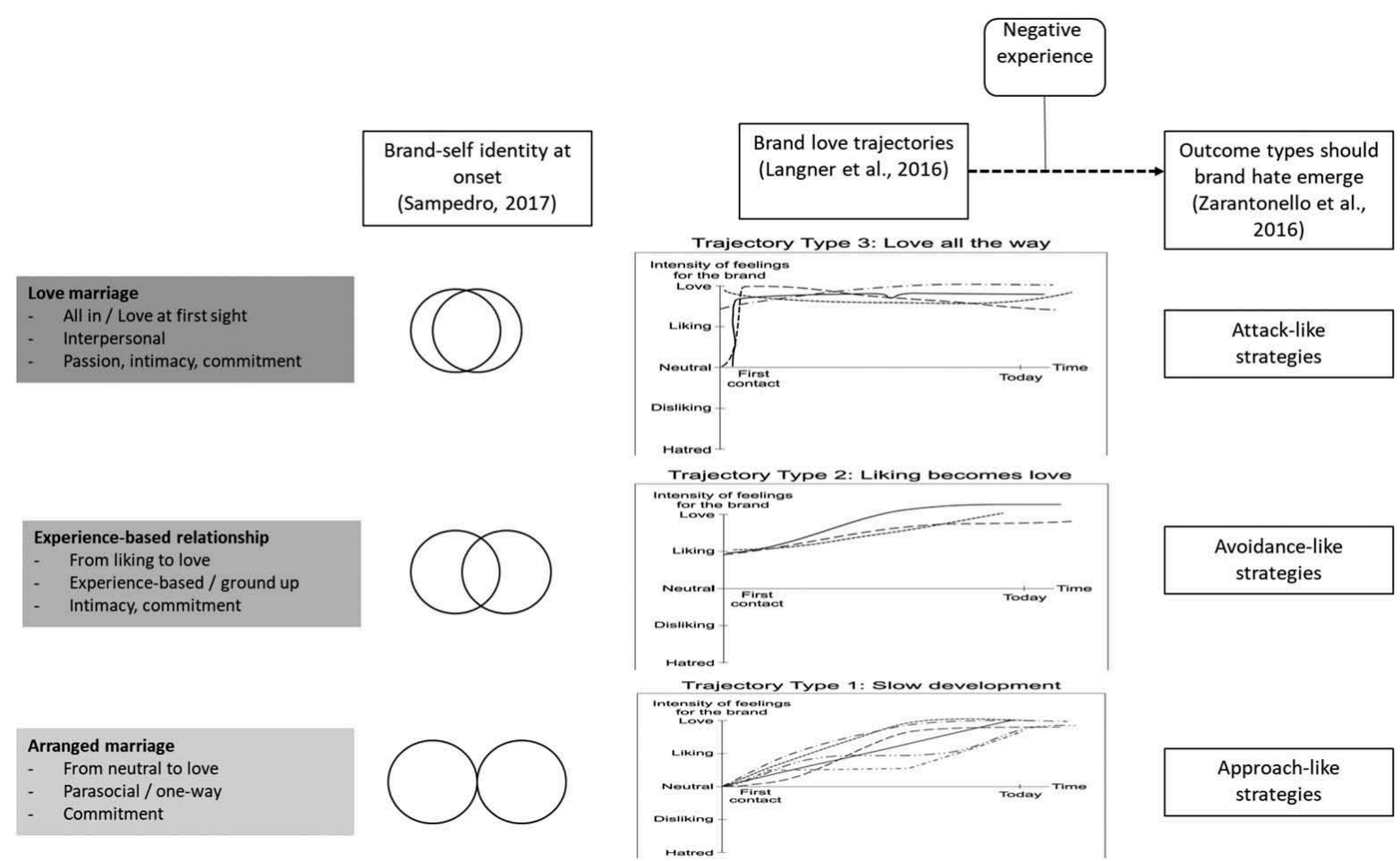

Figure 1. Relational typologies of brand love and brand hate.

brand's identity. This framework extends earlier work by Aron, Aron, Smollan, and Miller (1992) who proposed a similar continuum to represent the variation in people's inclusion of another in their self-concept. On one extreme of the continuum, there is a total lack of congruence, as depicted by two separate circles. On the other extreme, we find full congruence, where the circles representing the consumer's and the brand's identity essentially overlap. Sampedro (2017) and Reimann et al. (2012) conceptualise consumerbrand relationships to occur somewhere along this continuum.

Third, we use Langner et al. (2016)'s work to understand the different trajectories of brand love. Based on their longitudinal approach to identifying differences in consumers' experience and the relationship they form with their beloved brands, the authors established five different trajectories that vary by their onset (i.e. initial contact with the brand) and their development over time. More specifically, the authors distinguish between 1) slow development: a relationship that begins with a neutral feeling followed by a relatively slow upward transition; 2) liking becomes love: representing a transition from merely liking to actually loving a brand; 3 ) love all the way: capturing situations where love occurs early on and is maintained throughout the relationship trajectory; 4) bumpy road: describing a fluctuating and even erratic path; and 5) turnabout: initiated by a feeling of dislike towards the brand that evolves positively over time. This framework is interesting as it captures the different starting points, with some relationships starting out higher (as in love) versus lower (as in liking a brand or being neutral to a brand). Furthermore, their approach recognises that while some relationships can evolve in a positive direction over time, others may take more negative or mixed turns. It is important to note that for the purposes of our model, we only incorporate the first three of the five trajectories, as the last two (bumpy road and turnabout) present more sporadic and uneven forms that are not as clear and crystallised from a developmental standpoint. 
Finally, adopting the work of Zarantonello, Romani, et al. (2016), we incorporate brand hate as a potential element that may characterise the three relationship trajectories. This is particularly advantageous for brands given the detrimental consequences that may result should brand hate surface. The authors identify different strategies that are likely to emerge as brand hate manifestations, including avoidance-like strategies in response to negative brand perceptions and brand image; attack-like strategies in response to corporate wrongdoings; and approach-like strategies in response to violations of expectations. These strategies will be applied to match the three relationship forms, respectively.

In addition to the application of the above frameworks to our proposed conceptual model of brand love, we address another important shortcoming that characterises the extant literature. In particular, utilising the model, we differentiate between brand love and other proximal concepts, including satisfaction, brand liking, brand affection, brand commitment, brand trust, and brand attachment. At present, there is a fair amount of discrepancy in the literature as to how these constructs relate to brand love, and to what extent they can be used as interchangeable (Bergkvist \& Bech-Larsen, 2010).

\section{Love marriage between consumers and brands}

Love at first sight is a powerful phenomenon, and as such has been differentiated from more gradual love encounters (Sangrador \& Yela, 2000). When we fall madly in love, we tend to throw ourselves into the relationship all the way, experience greater passion and intensity, and identify with the other person to a large extent (Barelds \& Barelds-Dijkstra, 2007). Within interpersonal encounters, greater emphasis tends to be placed on physical appearance, and research also highlights the impact of dispositional traits like human personality and mate preferences (Riela et al., 2010). Similarities can be drawn between person-to-person and consumer-to-brand encounters. When consumers fall in love with brands in a love at first sight fashion, they exhibit intense and passionate emotions right from the start. Their developmental trajectories begin high and are also more likely to continue to remain high as well.

Love at first sight encounters are best envisioned in line with the interpersonal love framework, as there is a clear two-way interaction between the consumer and the brand. Consumers expect to receive delight as part of their brand-related experiences, and also continue to strive for such encounters over time. Albert and Merunka (2013)'s notion of trust is particularly relevant here in terms of the development of a love feeling, with particular attention to honesty and reliability. In the authors' brand love scale, items such as intimacy, dream, pleasure, memories, unicity, affection and passion are referenced as important building blocks of brand love. Similar positioning can be seen in the work of Albert et al. (2009) and Carroll and Ahuvia (2006), establishing connections to brands by using terms such as happiness, passion and delight. Within Sternberg (1986)'s love theory, the love marriage form of brand love is most likely to be characterised by high intimacy, high passion and high long-term commitment, which has been referenced as 'consummate love.' In Thomson et al.'s (2005) conceptualisation, these relationships tend to be high on affection, passion as well as connection, whereas in Fournier (1998)'s framework, the dimensions of love, passion, intimacy and interdependence are the most applicable dimensions.

Apple presents a good example to demonstrate love at first sight situations. Apple has been able to establish such a strong community base that people infatuated with the brand 
are more likely to purchase different products from the same brand, without considering alternatives. A true Apple lover is likely to have an iPhone, an iPad and a MacBook computer, as well as use iTunes and iCloud to go all the way. Given their extensive commitment, these consumers are less likely to switch to a PC environment or consider a Samsung phone. Apple has been able to achieve such a prominent position in consumer's minds given their extensive focus on continuous innovation that it provides consumers with enabling as well as enticing benefits that make their lives easier as well as more enjoyable (Park et al., 2016). In terms of brand outcomes, just as we tend to rave about our significant other when in love with them, consumers can do the same regarding brands, which in turn present brands with great advantages. There is obviously commitment, and loving consumers are more likely to engage positively with the brand, forgive occasional brand failures (Bauer et al., 2009; Donovan, Priester, MacInnis, \& Park, 2012) and remain loyal (Carroll \& Ahuvia, 2006).

Of the proximal constructs, brand affection, brand passion, brand trust, and brand attachment are the most prevalent in the case of the love marriage form of brand love. Brand affection captures a continuum of emotions that range from simple affect often expressed by ordinary words such as 'like' and 'appreciate' (Albert, Merunka, \& ValetteFlorence, 2010), to intense ones that resemble 'love.' Brand affection can be advantageous in eliciting favourable brand responses in consumers, which in turn may be related to customer loyalty (Thomson et al., 2005). In the interpersonal love literature, the concept of affection has been defined as 'feelings of closeness, connectedness, and bondedness in loving relationships' (Sternberg, 1997, p. 315), and has also been linked with intimacy (Hatfield, Schmitz, Cornelius, \& Rapson, 1988) and attachment (Fisher, 2006). Brand love can be viewed as an extreme form of affect towards a particular brand, which - beyond the heightened emotional intensity - may prevent negative feelings (i.e. dislike or hate) (Carroll \& Ahuvia, 2006). Some scholars define brand love and brand affection as analogous constructs (Batra et al., 2012), with brand love maintaining its unique status and ability to integrate the brand into the consumer's overall self-concept (Bıçakcıoğlu, İpek, \& Bayraktaroğlu, 2016; Carroll \& Ahuvia, 2006).

Passionate love within the interpersonal love literature has been defined as 'a state of intense longing for union with another' (Hatfield \& Walster, 1978, p. 9). Within contemporary consumer research, Thomson et al. (2005) described brand passion as 'intense and aroused positive feelings toward a brand' (p. 80). Frequently, brand passion is referred to as 'the zeal' (Keh, Pang, \& Peng, 2007, p. 84) that captures the 'enthusiasm, the infatuation or even the obsession of a consumer for a brand' (Albert \& ValetteFlorence, 2010, p. 2). It is a predominantly affective state characterised by extremely positive attitudes (Bauer, Heinrich, \& Martin, 2007, p. 2190), and high-intensity arousal towards a specific brand (Thomson et al., 2005). Consumers who feel passionate about a brand will establish an emotional connection with the brand, and will anticipate experiencing delight, along with a feeling of loss or anxiety when the brand is unavailable (Matzler, Pichler, \& Hemetsberger, 2007).

Similarly to passion within an interpersonal context, brand passion also entails the three building blocks of cognition, emotion and behaviour (Hatfield et al., 1988). The cognitive element is associated with the consumer's idealisation of the brand, while the emotional component concerns the level of attraction towards the brand and the desire to continue the relationship. Affect is particularly important in that it may evoke certain negative emotions associated with changes to key aspects of the brand, including brand 
image (Hatfield, 1988). Finally, the behavioural component involves actionable outcomes like purchasing behaviours, positive WOM, and positive publicity. Brand passion and brand love are often used interchangeably (Bergkvist \& Bech-Larsen, 2010), although some researchers position brand passion as an important component of brand love (Albert et al., 2008; Carroll \& Ahuvia, 2006).

Brand trust is a critical element of any successful consumer-brand relationship (Garbarino \& Johnson, 1999) and plays a key role in relational marketing (Morgan \& Hunt, 1994). Band trust refers to a strong belief in a given brand's reliability, altruism and honesty (Hess, 1995). This construct also embraces cognitive as well as affective components (Delgado-Ballester, Munuera-Alemán, \& Yagüe, 2003). The cognitive element builds on the consumer perceptions regarding brand promise and meeting expectations (Chaudhuri \& Holbrook, 2001). The affective experiential component is important to instil faith in the consumer regarding brand performance (Esch, Langner, Schmitt, \& Geus, 2006), which in turn may nurture the establishment a long-term customer-brand relationship (Albert \& Merunka, 2013). Research shows that brand trust tends to exert a positive influence on brand attitudes and purchase loyalty (Chaudhuri \& Holbrook, 2001), similarly to brand love. While brand trust is based on consumer expectations in terms of reliability, altruism and honesty, brand love entails additional and intense feelings that develop through continuous experiences with the brand (Albert \& Merunka, 2013). Moreover, brand trust has often been positioned as an important antecedent of brand love (Albert \& Merunka, 2013).

Finally, brand attachment relates to the thoughts and feelings associated with the relationship that forms between consumers and the brand (Chang \& Chieng, 2006; Loureiro, Ruediger, \& Demetris, 2012), and refers to the strength of a bond a consumer may establish with a given brand (Park et al., 2010). Consumers' close relationships with brands can be compared to interpersonal attachments, including celebrities (Thomson, 2006), product brands (Thomson et al., 2005), or place brands (Debenedetti, Oppewal, \& Arsel, 2014). Previous research revealed that attachment-based consumer-brand relationships are often differentiated by the extent of self-brand connection and brand prominence/salience (Park et al., 2013, 2010). Brand prominence - capturing the degree of cognitive and emotional connection between a consumer and the brand - is particularly important given its significance to instil and evoke consumer memories. In the case of strong brand attachments, consumers are more likely to establish pronounced cognitive and emotional connections, which in turn can be associated with higher likelihoods of brand relevant autobiographical memories (Park et al., 2010). In other words, in the case of strong brand attachment, consumers will be more likely to integrate the brand into their lives, and will also be more willing to dedicate greater resources (i.e. money, time, reputation) to maintaining a positive relationship with the brand. Importantly, through the moderating effect of brand self-connection and brand prominence, brand attachment has been shown to predict brand loyalty and brand advocacy; which are considered particularly advantageous from the perspective of brands (Park et al., 2013, 2010).

The reasons why consumers expand resources on a brand is likely to present the primary mechanism that differentiates brand attachment from brand love, as brand attachment relies on self-centeredness whereas brand love relies more on brandcenteredness (Park et al., 2013). Brand attachment is often referenced in conjunction with brand attitude strength, given their shared similarities concerning marketingrelevant outcomes. Park et al. (2010) differentiate between the two by arguing that 
'although the brand attitude strength construct may capture a brand's mindshare of a consumer, attachment is uniquely positioned to capture both heart and mind' (p. 14). Nonetheless, the exact boundaries between brand love and brand attachment remain blurred and relatively difficult to decipher (Carroll \& Ahuvia, 2006; Chang \& Chieng, 2006; Laros \& Steenkamp, 2005).

It is interesting to explore what may happen should consumers experience a negative encounter in relation to their beloved brand. These consumers are passionate about and committed to the brand, and embrace values that are congruent with those advocated by the brand. Consequently, instances of corporate wrongdoing can be quite detrimental. For a practical example, imagine being a new iPhone owner and reading about the lawsuits filed against Apple for slowing down old phones to push consumers into purchasing a new one; a news item that was prevalent in the media during late 2017 and early $2018{ }^{1}$ Given the high level of identity congruence and commitment between the consumer and the Apple brand, individuals may feel angry, betrayed and frustrated, which in line with Zarantonello et al.'s work, may result in attack-like coping strategies like active expression of discontent and negative WOM. Earlier research shows that stronger relationships tend to serve as a buffer that evokes greater tolerance and forgiveness on behalf of consumers to counter the negativity (Grégoire \& Fisher, 2008). Nonetheless, while these consumers' threshold may be higher to forgive a few instances of brand failure, prolonged disappointment, and particularly a violation of the fairness norm, may result in detrimental consequences for brands (Gregoire \& Fisher, 2008). Similarly to romantic relationships that build on open communication, trust and sharing, in order to deal with such situations, brands are advised to take a proactive approach and respond to consumer complaints as early as possible (Zarantonello, Romani, et al., 2016).

\section{Experience-based relationships between consumers and brands}

The second trajectory depicted in Figure 1 concerns those situations when brand love evolves gradually on the basis of consumers' collection of experiences with the brand over time and may advance in a positive direction provided that the experiences continue favourably. There is some congruence between the consumer's identity and that of the brand at the onset of the relationship, as evidenced by the overlap between the two respective circles representing consumer identity and brand identity, yet the congruence is not as great as in the case of the love at first sight scenario. In these situations, the consumer is likely to explore different alternatives prior to pursuing the brand and to make a conscious choice. Batra et al. (2012) list a wide range of reasons why consumers may become brand lovers over time. These include attractive brand qualities; values and existential meaning; intrinsic rewards; self-identity; positive affect; passionate desire and fit; emotional bonding and anticipated heartbreak; willingness to invest; frequent thought and use; and length of use. Given their initial exploration and choice, consumers in these scenarios begin by liking the brand and thus display a generally positive attitude towards the brand at the first point of contact, but then over time and with accumulated experience may grow to like the brand even further (Langner et al., 2016).

Consumers in the experience-based typology do not go all the way as their love at first sight counterparts do, and thus are more likely to maintain their safer distance at least early on. They may experiment with different features; pay attention to quality and 
service; and take greater caution to settle for the brand in the long run. An example may be when a consumer is in the market for a new phone. They are likely to consider various product attributes including design, performance and price, as well as the behaviour of their peer group and recommendations from within their social circles. At the end of their evaluation process, they end up deciding to purchase an iPhone. Although somewhat more expensive in comparison to other options, most of their friends have an iPhone, and they also appreciate some of its unique features. Despite their decision and commitment to purchase an iPhone, in contrast with their love at first sight counterparts, they are not yet ready to go all the way and purchase other Apple products. Instead, they explore their new iPhone and gradually assess their encounters. Should these evaluations be positive, they may gradually become brand lovers and may consider purchasing other Apple products in the future.

Within Sternberg (1986)'s typology, experience-based relationships entail higher degrees of intimacy and commitment, but lower degrees of passion, entailing rational choice and contemplation. Of the existing brand love scales, Batra et al. (2012) and Bagozzi et al. (2017) are the most relevant, with Thomson et al. (2005)'s conceptualisation suggesting low passion, average affection, and high connection, while in Fournier (1998)'s theory medium self-connection and high partner quality. Importantly, consumers have to maintain brand satisfaction to ensure prolonged involvement. Of the proximal constructs, satisfaction and brand liking are the most relevant.

Satisfaction captures a positive evaluation following consumption (Mano \& Oliver, 1993) ranging from low to high intensity (Ha \& Perks, 2005). According to prior research, as the intensity of a developing relationship increases, so does brand satisfaction, which over time may yield beneficial outcomes such as brand trust and brand loyalty (Fournier \& Yao, 1997; Horppu, Kuivalainen, Tarkiainen, \& Ellonen, 2008) and higher purchase intentions (Eagly \& Chaiken, 1993). Satisfaction is advantageous not only by producing a cognitive judgment but also by leading to longer-term emotional attachment (Thomson et al., 2005; Whang et al., 2004). Consequently, satisfaction has been identified as an important antecedent of brand love, yet one that is not sufficient in and of itself (Albert et al., 2008; Carroll \& Ahuvia, 2006; Drennan et al., 2015).

Fournier and Mick (1999) conceptualise brand love as a mode of satisfaction that is experienced by some customers but not by all. According to this view, satisfaction is positioned as a more macro-level variable. Carroll and Ahuvia (2006) offer further points of distinction. First, they view satisfaction as a cognitive judgment whereas brand love as a concept that entails a stronger affective charge. Second, they position satisfaction as a transaction-specific outcome, whereas they view brand love as a result of a long-term relationship between the consumer and the brand; one that has the potential to improve over time (Thomson et al., 2005). Third, although satisfaction is often linked with expectancy disconfirmation, the same is not necessarily the case for consumers who love a brand, as they already know what to expect from the brand. Finally, consumers who love a brand are more likely to integrate the brand into their identity; a notion that is not evident in more general experiences of satisfaction.

In line with Park et al. (2016)'s propositions, brand love emerges on the basis of enticing benefits that play into consumer cognition as well as affect. On the cognitive side, brands need to stimulate consumer cognition and senses, whereas on the affective side they need to elicit sensations that 'warm the heart,' triggering warmth, gratitude, 
empathy and nostalgia. On the basis of these enticing benefits, consumers will experience gratification, engagement, entertainment and warmth, which in turn collectively induce brand love. The model also presents the key brand love outcomes discussed above. Perceived product quality is particularly prevalent here with its links with trustworthiness, good performance, and attractive design which have been shown to have the potential to induce brand love (Batra et al., 2012). In this sense, outstanding quality may be viewed as a 'status-quo' expectation, and its absence may interfere with ultimately achieving or maintaining brand love over time (Batra et al., 2012).

Brand liking and brand love both encompass some rationality related to product quality requirements along with a range of positive emotions (Langner et al., 2015; Rossiter, 2012), although the emotional element tends to be more pronounced in the case of brand love, in turn linked with higher likelihoods of brand purchase, usage rates and brand recommendations (Rossiter, 2012). Consumers also tend to use superlative emotional descriptions (i.e. this brand is super, it's brilliant, it's excellent, I love this brand) when describing their relationship to beloved brands (Langner et al., 2015). In terms of a temporal variation, while brand liking can be sporadic and lack prior history or association, brand love tends to originate on the basis of certain key events or past memories, sometimes reaching as far back as the consumer's childhood (Langner et al., 2015).

In a relationship context, liking tends to entail a reciprocal exchange commitment among equal peers, like in the case of friendships. Applying this to consumer-brand dyads, brand liking tends to be conditional in that consumers expect an equal exchange between themselves and the brand that rewards them for their own commitments (Langner et al., 2015). This condition is not as prevalent in the case of brand love, where inequality is more tolerated, similarly to a mother's unconditional love towards her child (Sternberg, 1986). Importantly, brand love tends to have a longer-term orientation and is frequently associated with fear of loss and separation anxiety; emotions that are not characteristic of brand liking (Langner et al., 2015; Rossiter, 2012).

Regarding the potential emergence of brand hate during the consumer-brand relationship, the situation here is likely to resemble avoidance-like strategies that include patronage reduction or cessation. While consumers may be able and willing to forgive some negative encounters, once they occur repeatedly, they may gradually distance themselves and ultimately reach a point where they wish to end the relationship and seek divorce; an outcome that in the branding context resembles an avoidance-like coping strategy. In order to turn such a situation around, brands need to actively engage and incentivise consumers to counter their negative experience and reconsider returning to their brand.

\section{Arranged marriage between consumers and brands}

The third and final category represented in Figure 1 concerns scenarios where consumers have no prior experience with a brand and thus are initially neutral, but may over time grow to like or even love the brand. Consequently, there is no overlap or congruence between the identity of the consumer and that of the brand at the onset of the consumer-brand relationship, hence the complete separation between the two circles. The analogy of arranged marriages can be used to represent these situations, as in an arranged marriage the two parties do not have any prior knowledge or experience with each other. There is commitment early on, but the relationship is understandably neutral 
or even cold at first and may gradually move from neutral to liking and potentially love. Consequently, Sternberg (1986)'s typology would indicate low passion and intimacy with high commitment corresponding to 'empty love,' along with Thomson et al.'s (2005) low passion, low affection and high connection. Of the dimensions from Fournier (1998), commitment is the most prevalent. Returning to our earlier example, imagine a consumer who is given an iPhone by their organisation, which also happens to be their very first smartphone. The platform, the purpose, the integrated user experience, and many other aspects are entirely different from prior cell phones, presenting the user with an entirely new experience. The iPhone holds a lot of new possibilities, but it is up to the consumer to take advantage of them. When the relationship is successful, the consumer may begin to form deeper relationships with the brand and may over time establish synergies with their own identity that may facilitate loving the brand.

Of the three different theoretical lenses applied to the brand love concept, unidirectional or parasocial relationship forms (Fetscherin, 2014) may be best to approximate these consumer-brand relationships, at least during their onset. In contrast with the bidirectional nature of interpersonal love, these relationships are better envisioned as oneway and - at least initially - unreciprocated. Couples entering into an arranged marriage are likely to have at least some expectations as to what a marriage is likely to entail, but whether or not those expectations are met will depend on their experience. Couples begin to build their relationship by engaging in conversations, activities and other shared encounters that over time enable them to establish a common history. In the branding context, such relationships were paralleled with feelings of friendship or intimacy towards media celebrities or famous people (Cohen, 1997; Currás-Pérez et al., 2011; Schmid \& Klimmt, 2011), which then have been applied to objects and brands as well (Fetscherin, 2014).

Brand commitment is the most salient proximal construct in this typology, referring to a behavioural reaction that entails a generally positive attitude and willingness to maintain a relationship with a brand (Evanschitzky, lyer, Plassmann, Niessing, \& Meffert, 2006), encompassing both affect and continuance (Albert \& Merunka, 2013). The affective element is an emotion based on identification, value sharing, trust and attachment (Evanschitzky et al., 2006), while continuance involves the unwillingness to switch to another brand and a general view of scarcity regarding substitutes (Fullerton, 2005). Brand commitment has been positively associated with positive WOM and willingness to pay a premium price (Albert \& Merunka, 2013), similarly to brand love outcomes. Most conceptualisations position brand commitment as an antecedent of brand love (Albert \& Merunka, 2013).

Following their initial externally-imposed commitment, consumers enter a stage of exploration and begin building a history with the brand. The new iPhone user is likely to experiment with different applications and benefit from the multitude of features offered by their new technology. When their trajectory is positive, they may eventually grow to like or even love the brand. However, after enduring negative experiences, brand hate may also emerge especially in response to violations of expectations, which may be manifested in approach-like coping strategies such as complaining and protest. In the absence of initial passion and intimacy, consumers may respond to frustrations or brand failure in a less forgiving fashion than their love at first sight counterparts. However, given their limited choice or ability to switch to another brand, they also may be more likely than the experience-based consumers to simply voice their 
discontent but otherwise remain more passive. Should brands wish to remedy such consequences, it is recommended that they become as open with their consumers as possible (Zarantonello, Romani, et al., 2016).

Building on the proposed model, it is advantageous to revisit existing definitions for brand love. The primary working definition assumed in most studies comes from Carroll and Ahuvia (2006), according to which brand love refers to the degree of passionate and intense emotional feelings and attachment towards a brand. In our proposed framework, the applicability of this definition depends on the developmental trajectory characterising the consumer-brand relationship. While for the love marriage form, the definition would apply at the onset of the relationship and beyond, in the other two forms of brand love it only develops over time. Hence, we offer a slightly revised definition that captures the theoretical complexity and developmentally dynamic nature of brand love. We conceptualise brand love as an intensive emotional connection characterised by intimacy, passion and commitment, which may emerge at the initial consumer-brand encounter, but may also develop over time, based on delightful experiences and/or shared history.

\section{So what does it all mean for brands?}

The above section introduced our conceptual model proposed to offer a comprehensive approach to the concept of brand love. Our framework is novel in various ways. First, in comparison to earlier work that took a largely cross-sectional and snapshot view to brand love, we embraced a developmental perspective to take into account the evolution of brand love along different trajectories. Second, instead of selecting between the different theoretical lenses used in earlier research to position brand love, our model incorporates all three. This is advantageous as it helps clarify the present discrepancies in defining and positioning brand love. We argued that consumers should be differentiated by the onset, the extent of self-brand congruence, and the trajectory evolution characterising their relationship. Without such a developmental approach, brand love cannot be understood fully. In fact, our model demonstrates that brand love during the early stages of a consumer-brand relationship can only be discussed in relation to our love marriage typology, where customers fall in love with the brand from the start, feeling passion, intimacy and commitment. In the other two relationship forms, brand love emerges over time, but only after building up considerable history between the consumer and the brand. This has important implications for scale development and measurement purposes, advising scholars to not only ask participants about their relationships with brands at any given time, but also prompt them to understand their developmental trajectory.

Third, we established an association between brand love and certain key proximal constructs. In particular, brand affection, brand passion, brand trust and brand attachment were linked to the love marriage scenario; satisfaction and brand liking - with a strong emphasis on product quality and brand image - to experience-based relationships, and finally commitment to the arranged marriage scenario. Such differential positioning is important to help scholars and practitioners understand consumer preferences and choice more fully, and to use the appropriate terminology depending on the type of love between the consumer and the brand. Finally, in our model development, we acknowledged the important role of brand hate, which has been largely overlooked in prior brand love conceptualisations. Within a developmental trajectory 
approach, it becomes clear that brand love cannot be taken for granted, and unless continued product and service quality and general satisfaction are met, negative consequences may prevail (Grégoire et al., 2009; Zarantonello, Romani, et al., 2016). Although further research is needed to test these associations empirically, such a differentiation provides a meaningful starting point for scholars to work with.

One important question is how companies can make their consumers fall in love with their brand, which is relevant to inform branding decisions in the areas of strategy and consumer segmentation (Vlachos \& Vrechopoulos, 2012). In theory, all brands should aim to become loved by consumers. When a consumer loves a brand, the choice is made, similarly to when we do not consider an alternative partner when we are in love with someone. Yet as our model illustrated, the path different consumers take may vary from one another, and thus a one size fits all strategy may not be successful to reach all customers. The love all the way scenario may be particularly advantageous for brands as they may be able to 'get away with more' in the case of consumers who are infatuated with their brand. These consumers establish a symbolic connection with their beloved brand and can identify extensive synergies between the brand's and their own identity. Self-congruity, defined as 'the match between consumers' self-concept and the user image of a given product, store, sponsorship event, etc.' (Sirgy, Lee, Johar, \& Tidwell, 2008 , p. 1091) contributes to brand identification, representing the fit between the consumer and the brand's image, values and personality (Bergkvist \& Bech-Larsen, 2010; Escalas \& Bettman, 2003) which in turn elicits deeper bonds and more pronounced brand love (Albert \& Merunka, 2013; Bıçakcıoğlu et al., 2016).

Our model emphasised that early experiences with a brand can be particularly important in setting the consumer on a given track. Along these lines, brand image and brand personality become relevant. Becheur, Bayarassou, and Ghrib (2017) studied the impact of brand personality on affective consumer commitment. The authors found evidence that the agreeableness component of brand personality, including conviviality, seduction and creativity positively affected most brand love dimensions. Brands should place special emphasis on convivial aspects, given their role in enhancing memory, intimacy and idealisation; all important precursors to ensure affective commitment (Roy, Khandeparkar, \& Motiani, 2016).

Not all consumers are equally prone to experience the same type of consumer-brand relationships, with variations based on consumer characteristics. For instance, of the Big Five personality attributes (McCrae \& John, 1992), openness was found to have a significant predictive role in eliciting brand love (Voorn, Hegner, \& Pruyn, 2015). This may be the case given that openness requires an active imagination, aesthetic sensitivity, and intellectual curiosity (McCrae \& John, 1992). Furthermore, anthropomorphism, defined as 'the tendency to imbue the real or imagined behaviour of nonhuman agents with humanlike characteristics, motivations, intentions, or emotions' (Epley, Waytz, \& Cacioppo, 2007, p. 100), has been shown to exert further impact on brand love (Rauschnabel \& Ahuvia, 2014), although available research in this area remains limited.

The emotional attachment relationships that consumers form towards brands not only reflect on their perception of themselves, but also on the ways in which they want to present themselves to others (Matzler, Pichler, Füller, \& Mooradian, 2011; Wallace et al., 2014). Consequently, brand love may be particularly prevalent in the case of selfexpressive brands (Park et al., 2010), which ties in with our earlier discussion of brand 
personality. According to Carroll and Ahuvia (2006), a self-expressive brand can be defined as 'the consumer's perception of the degree to which the specific brand enhances one's social self and/or reflects one's inner self' (p. 82). Hence, consumers may purchase a luxury brand to project a particular lifestyle and social status, or to identify themselves in a certain way that is enabled by the brand.

With respect to group influences, a strong social identity, defined as an 'individual's self-concept which derives from his knowledge of his membership of a social group together with the value and emotional significance attached to that membership' (Tajfel, 1981 , p. 185), was also found to have a positive impact on brand love (Vernuccio, Pagani, Barbarossa, \& Pastore, 2015). Particularly within the service industry, interpersonal antecedents, including gratitude, partner quality and social support were suggested to play an important role for eliciting brand love (Long-Tolbert \& Gammoh, 2012). Because service businesses depend largely on human input, the more positive the interpersonal relationship that forms between the consumer and the service provider, the greater the likelihood of brand love experienced in relation to the service brand.

As an important caveat, research indicates that not all product categories are equally salient to become the focus of consumer love. For instance, although both utilitarian and hedonic product attributes impact consumer behaviour (Babin, Darden, \& Griffin, 1994; Collins, Kavanagh, Cronin, \& George, 2014; Fetscherin, Boulanger, Gonçalves Filho, \& Quiroga Souki, 2014; Hirschman \& Holbrook, 1982; Kahneman, Diener, \& Schwarz, 2003; Papagiannidis, Pantano, See-To, \& Bourlakis, 2013; Voss, Spangenberg, \& Grohmann, 2003), hedonic products tend to be superior in their ability to elicit positive and strong consumer brand relationships (Carroll \& Ahuvia, 2006; Chaudhuri \& Hoibrook, 2001; Huber et al., 2015; Karjaluoto et al., 2016). Of the hedonic features, aspects of fun and enjoyment (Carroll \& Ahuvia, 2006), fantasy and pleasure (Joji \& Ashwin, 2012), and aesthetic characteristics stand out (Hirschman \& Holbrook, 1982). The heightened emotional reactions induced by hedonic products may result in strong psychological feelings that over time could approximate love (Chandon, Wansink, \& Laurent, 2000), especially in the case of self-expressive brands (Carroll \& Ahuvia, 2006).

One final important antecedent for brand love concerns culture, which has obvious implications for how people approach the notion of love. Generally speaking, individualistic societies tend to instil the importance of freedom, personal choice and individual responsibility and competition in their members, while collectivist cultures tend to espouse family, community, sharing and group goals (House, Hanges, Javidan, Dorfman, \& Gupta, 2004; Kagitcibasi, 2005). In individualistic societies, emotions are viewed as important aspects of one's self and identity, while in collectivistic nations emotions tend to serve more as a foundation for social interactions (Wang, 2001). Along these lines, falling in love can also be experienced differently in different cultural settings (Riela et al., 2010), many viewing love marriage as an individualist endeavour, while arranged marriage as a largely collectivist one (lyengar, 2011). These findings have obvious implications for brands in assisting them to achieve a fuller understanding of how brand love is established, develops and evolves over time.

\section{Discussion and future research directions}

This paper assessed the present state of research and expanded upon available conceptual understandings of brand love. From a conceptual standpoint, we advocated 
a dynamic view of brand love incorporating the three dominant theoretical lenses. Importantly, we advocate a developmental trajectory approach to brand love. We argue that brand love should not be viewed as static but rather as continually evolving, incorporating each and every encounter and new brand-related experience that may alter the future course of the consumer-brand relationship. While additional work is needed to empirically test out the proposed model and ultimately achieve a more comprehensive understanding of consumer profiles within the three scenarios, the framework nonetheless provides greater conceptual clarity. In addition to the three primary frameworks employed, the application of additional conceptual lenses, including motivational analyses and goal theory (Bagozzi \& Dholakia, 1999; Epp \& Price, 2011; Locke \& Latham, 2006; Pintrich, 2000) would be advantageous.

Future research should explore antecedents and moderators of brand love more fully, within as well as across the different consumer-brand scenarios. Some earlier research exists, but as most take a snapshot view of brand love, it remains unclear whether the impact would remain the same after adopting a developmental perspective. In terms of moderators, scholars emphasise the importance of demographics (e.g. income, age, gender), extent of customer involvement (Kaufmann, Loureiro, \& Manarioti, 2016), product category (Kaufmann et al., 2016), brand characteristics (e.g. luxury vs non-luxury brands) (Hegner, Fenko, \& Teravest, 2017), user behaviours (e.g. heavy users vs light users) (Roy et al., 2016), different types of retail stores (Roy et al., 2016), personality characteristics (Hegner et al., 2017) and cultural influences (Kaufmann et al., 2016; Roy et al., 2016), with additional work required to understand their precise impact and contribution.

Cross-cultural studies remain limited and sporadic, warranting further research. Furthermore, cultural variations are important for scale development, and the terminology used in questionnaires in reference to brand love is important and warrants further considerations (Rossiter, 2012). The vast majority of available research on brand love is based on quantitative and survey-based analyses, which present additional challenges in the case of an inherently complex phenomenon. Future research should engage in more qualitative explorations, combining in-depth interviews with other creative visual options (e.g. the ZMET, Coulter \& Zaltman, 1994) in order to tap into certain aspects of brand love that may be outside of the direct awareness of individuals, and thus harder to capture using survey tools. Finally, the multifaceted relationship between brand love and brand hate should be explored empirically, adopting a developmental approach to understand different associations and trajectories.

In conclusion, our proposed conceptual model for brand love addresses ongoing debates in the field and thus complements the literature in a substantive fashion. By positioning brand love in a developmental perspective that distinguishes between different brand love scenarios based on self-brand congruence and trajectory evolution, we addressed important limitations and discrepancies in the field and advanced conceptualisations that enable a more comprehensive and coherent understanding of brand love. Nevertheless, a great amount of untapped potential remains in this area of inquiry, with further benefits and value for scholars and practitioners alike. 


\section{Note}

1. https://www.wsj.com/articles/apple-faces-multiple-lawsuits-over-throttled-iphones -1522229400 .

\section{Disclosure statement}

No potential conflict of interest was reported by the authors.

\section{Notes on contributors}

Narissara Palusuk is a PhD candidate at Rennes School of Business in France. She completed Msc. Marketing Management (Merit) from Aston University, UK. She is also a lecturer at Khon Kaen University in Thailand and the KKU PhD scholarship recipient.

Bernadett Koles is an Associate Professor of Marketing and Consumer Behaviour at Rennes School of Business, France. She holds a doctorate from Harvard University in Psychology, and is currently pursuing a PhD in Marketing at Durham Business School in the UK. Her research covers a range of areas reflecting upon her multidisciplinary expertise. Her present interests focus on compensatory consumption, consumer compromise, and the impact of innovative technologies on consumers and organisations. Prior to joining RSB, she held positions in the United States, Portugal, and Hungary.

Rajibul Hasan is an Assistant Professor of Marketing at the Rennes School of Business, France. He completed his PhD from the University of Kent and the recipient of a Kent Business School PhD Scholarship. His other research interests include consumer behaviour, diffusion of innovation, technology acceptance models, ethics in marketing, Bottom of Pyramid market, and poverty alleviation.

\section{ORCID}

Bernadett Koles (1) http://orcid.org/0000-0002-7185-050X

\section{References}

Aaker, J. (1997). Dimensions of brand personality. Journal of Marketing Research, 34(3), 347-356.

Aggarwal, P. (2004). The effects of brand relationship norms on consumer attitudes and behavior. Journal of Consumer Research, 31(1), 87-101.

Ahuvia, A. C. (1993). I love it! Towards a unifying theory of love across diverse love objects (PhD Dissertation). Northwestern University.

Ahuvia, A. C. (2005). Beyond the extended self: Loved objects and consumers' identity narratives. Journal of Consumer Research, 32(1), 171-184.

Albert, N., \& Merunka, D. (2013). The role of brand love in consumer-brand relationships. Journal of Consumer Marketing, 30(3), 258-266.

Albert, N., Merunka, D., \& Valette-Florence, P. (2008). When consumers love their brands: Exploring the concept and its dimensions. Journal of Business Research, 61(10), 1062-1075.

Albert, N., Merunka, D., \& Valette-Florence, P. (2009). The feeling of love toward a brand: Concept and measurement. Advances in Consumer Research, 36(1993), 300-307.

Albert, N., Merunka, D., \& Valette-Florence, P. (2010). Passion for the brand and consumer brand relationships. In Australian \& New Zeland marketing academy conference (pp. 1-9). Dunedin, AU: Australian and New Zealand Marketing Academy.

Albert, N., \& Valette-Florence, P. (2010). Measuring the love feeling for a brand using interpersonal love items. Journal of Marketing Development and Competitiveness, 5(2006), 57-63. 
Aron, A., Aron, E. N., Smollan, D., \& Miller, N. (1992). Inclusion of other in the self scale and the structure of interpersonal closeness. Journal of Personality and Social Psychology, 63(4), 596-612.

Assael, H. (1987). Consumer behavior and marketing action (pp. 1-13). Boston: Kent Publishing Co. doi:10.1016/0167-8116(88)90003-1

Babin, B. J., Darden, W. R., \& Griffin, M. (1994). Work and/or fun: Shopping measuring value hedonic and utilitarian. Journal of Consumer Research, 20(4), 644-656.

Bagozzi, R. P., Batra, R., \& Ahuvia, A. (2017). Brand love: Development and validation of a practical scale. Marketing Letters, 28(1), 1-14.

Bagozzi, R. P., \& Dholakia, U. (1999). Goal setting and goal striving in consumer behavior. Journal of Marketing, 63, 19.

Barelds, D. P. H., \& Barelds-Dijkstra, P. (2007). Love at first sight or friends first? Ties among partner personality trait similarity, relationship onset, relationship quality, and love. Journal of Social and Personal Relationships, 24(4), 479-496.

Batra, R., Ahuvia, A., Bagozzi, R. P., \& Love, B. (2012). Brand love. Journal of Marketing, 76(2), 1-16.

Bauer, H., Heinrich, D., \& Martin, I. (2007). How to create high emotional consumer-brand relationships? The causalities of brand passion. In Proceedings of the Australian \& New Zealand marketing academy conference (pp. 2189-2198). doi: 10.1007/s10551-012-1216-7

Bauer, H. H. H., Albrecht, C. C.-M., \& Heinrich, D. (2009). All you need is love: Assessing consumers' brand love. Proceedings of the American Marketing Association Summer Educators Conference, 15 (2), 252-253.

Becheur, I., Bayarassou, O., \& Ghrib, H. (2017). Beyond brand personality: Building consumer-Brand emotional relationship. Global Business Review, 18(35), 1-17.

Bergkvist, L., \& Bech-Larsen, T. (2010). Two studies of consequences and actionable antecedents of brand love. Journal of Brand Management, 17(7), 504-518.

Bıçakcıoğlu, N., İpek, İ., \& Bayraktaroğlu, G. (2016). Antecedents and outcomes of brand love: The mediating role of brand loyalty. Journal of Marketing Communications, 7266(May), 1-15.

Carroll, B. A., \& Ahuvia, A. C. (2006). Some antecedents and outcomes of brand love. Marketing Letters, 17(2), 79-89.

Castaño, R., \& Eugenia Perez, M. (2014). A matter of love: Consumers' relationships with original brands and their counterfeits. Journal of Consumer Marketing, 31(6/7), 475-482.

Chandon, P., Wansink, B., \& Laurent, G. (2000). A benefit congruency framework of sales promotion effectiveness. Journal of Marketing, 64(4), 65-81.

Chang, P. L., \& Chieng, M. H. (2006). Building consumer-brand relationship: A cross-cultural experiential view. Psychology and Marketing, 23, 927-959.

Chaudhuri, A., \& Hoibrook, M. B. (2001). The chain of effects from brand trust and brand affect to brand performance: The role of brand loyalty. Journal of Marketing, 65(2), 81-93.

Chung, C. M. Y., \& Darke, P. R. (2006). The consumer as advocate: Self-relevance, culture, and word-of-mouth. Marketing Letters, 17(4), 269-279.

Cohen, J. (1997). Parasocial relations and romantic attraction: Gender and dating status differences. Journal of Broadcasting \& Electronic Media, 41(4), 516-529.

Collins, A., Kavanagh, E., Cronin, J., \& George, R. (2014). Money, mavens, time, and price search: Modelling the joint creation of utilitarian and hedonic value in grocery shopping. Journal of Marketing Management, 30(7-8), 719-746.

Coulter, R. H., \& Zaltman, G. (1994). Using the Zaltman metaphor elicitation technique to understand brand images. Advances in Consumer Research, 21, 501-507.

Currás-Pérez, R., Ruiz-Mafé, C., \& Sanz-Blas, S. (2011). What motivates consumers to teleshopping?: The impact of TV personality and audience interaction. Marketing Intelligence \& Planning, 29(5), 534-555.

Debenedetti, A., Oppewal, H., \& Arsel, Z. (2014). Place attachment in commercial settings: A gift economy perspective. Journal of Consumer Research, 40(5), 904-923.

Delgado-Ballester, E., Munuera-Alemán, J. L., \& Yagüe-Guillén, M. J. (2003). Development and validation of a brand trust scale. International Journal of Market Research, 45(1), 35-56.

Donovan, L. A. N., Priester, J. R., Maclnnis, D. J., \& Park, C. W. (2012). Brand forgiveness: How close brand relationships influence forgiveness. In B. Fournier, Fetscherin, \& Melewar (Eds.), Consumer-brand relationships: Theory and applications (pp. 184-203). Routledge. doi:10.4324/9780203128794 
Drennan, J., Bianchi, C., Cacho-Elizondo, S., Louriero, S., Guibert, N., \& Proud, W. (2015). Examining the role of wine brand love on brand loyalty: A multi-country comparison. International Journal of Hospitality Management, 49(August), 47-55.

Du, S., Bhattacharya, C. B., \& Sen, S. (2007). Reaping relational rewards from corporate social responsibility: The role of competitive positioning. International Journal of Research in Marketing, 24(3), 224-241.

Eagly, A. H., \& Chaiken, S. (1993). Psychology of attitudes. Orlando, FL: Harcourt, Brace, \& Jovanovich. doi:10.1016/j.anifeedsci.2011.04.090

Epley, N., Waytz, A., \& Cacioppo, J. T. (2007). On seeing human: A three-factor theory of anthropomorphism. Psychological Review, 114(4), 864-886.

Epp, A. M., \& Price, L. L. (2011). Designing solutions around customer network identity goals. Journal of Marketing, 75(2), 36-54.

Escalas, J. E., \& Bettman, J. R. (2003). You are what they eat: The influence of reference groups on consumers' connections to brands. Journal of Consumer Psychology, 13(3), 339-348.

Esch, F., Langner, T., Schmitt, B. H., \& Geus, P. (2006). Are brands forever? How brand knowledge and relationships affect current and future purchases. Journal of Product \& Brand Management, 15(2), 98-105.

Evanschitzky, H., lyer, G. R., Plassmann, H., Niessing, J., \& Meffert, H. (2006). The relative strength of affective commitment in securing loyalty in service relationships. Journal of Business Research, 59(12), 1207-1213.

Far, M. S., \& Dinani, H. G. (2015). Investigating effect rate of brand love on mouth marketing and consumers' purchase intention. Indian Journal of Fundamental and Applied Life Sciences, 5(S4), 1450-1457.

Fetscherin, M. (2014). What type of relationship do we have with loved brands? Journal of Consumer Marketing, 31(6/7), 430-440.

Fetscherin, M., Boulanger, M., Gonçalves Filho, C., \& Quiroga Souki, G. (2014). The effect of product category on consumer brand relationships. Journal of Product \& Brand Management, 23(2), 78-89.

Fisher, H. (2006). Pourquoi nous aimons. Paris: Robert Laffont.

Fournier, S. (1998). Consumers and their brands: Developing relationship theory in consumer research. Journal of Consumer Research, 24(4), 343-353.

Fournier, S., \& Mick, D. G. (1999). Rediscovering satisfaction. Journal of Marketing, 63(4), 5-23.

Fournier, S., \& Yao, J. L. (1997). Reviving brand loyalty: A reconceptualization within the framework of consumer-brand relationships. International Journal of Research in Marketing, 14(5), 451-472.

Fullerton, G. (2005). The service quality-loyalty relationship in retail services: Does commitment matter? Journal of Retailing and Consumer Services, 12(2), 99-111.

Garbarino, E., \& Johnson, M. S. (1999). The different roles of satisfaction, trust, and commitment in customer relationships. Journal of Marketing, 63(2), 70-87.

Grégoire, Y., \& Fisher, R. J. (2008). Customer betrayal and retaliation: When your best customers become your worst enemies. Journal of the Academy of Marketing Science, 36(2), 247-261.

Grégoire, Y., Tripp, T. M., \& Legoux, R. (2009). When customer love turns into lasting hate: The Effects of relationship strength and time on customer revenge and avoidance. Journal of Marketing, 73(6), 18-32.

Gupta, U., \& Singh, P. (1982). Exploratory study of love and liking and types of marriage. Indian Journal of Applied Psychology, 19, 92-97.

Ha, H.-Y., \& Perks, H. (2005). Effects of consumer perceptions of brand experience on the web: Brand familiarity, satisfaction and brand trust. Journal of Consumer Behaviour, 4(6), 438-452.

Hatfield, E. (1988). Passionate and companionate love. In R. J. Sternberg \& M. L. Bames (Eds.), The psychology of love (pp. 191-217). New Haven, CT: Yale University Press.

Hatfield, E., Schmitz, E., Cornelius, J., \& Rapson, R. L. (1988). Passionate love: How early does it begin. Journal of Psychology \& Human Sexuality, 1(1), 35-51.

Hatfield, E., \& Sprecher, S. (1986). Measuring passionate love in intimate relationships. Journal of Adolescence, 9(4), 383-410.

Hatfield, E., \& Walster, G. W. (1978). A new look at love. Lantham, MA: University Press of America. 
Hegner, S. M., Fenko, A., \& Teravest, A. (2017). Using the theory of planned behaviour to understand brand love. Journal of Product \& Brand Management, 26(1), 26-41.

Hendrick, C., \& Hendrick, S. (1986). A theory and method of love. Journal of Personality and Social Psychology, 50(2), 392-402.

Hess, J., Story, J., \& Danes, J. (2011). A three-stage model of consumer relationship investment. Journal of Product \& Brand Management, 20(1), 14-26.

Hess, J. S. (1995). Construction and assessment of a scale to measure consumer trust. In B. B. Stern \& G. M. Zinkhan (Eds.), AMA educators' conference, enhancing knowledge development in marketing (Vol. 6, pp. 20-25). Chicago, IL: American Marketing Association.

Hirschman, E. C., \& Holbrook, M. B. (1982). Hedonic consumption: Emerging concepts, methods and propositions. Journal of Marketing, 46(3), 92-101.

Horppu, M., Kuivalainen, O., Tarkiainen, A., \& Ellonen, H. (2008). Online satisfaction, trust and loyalty, and the impact of the offline parent brand. Journal of Product \& Brand Management, 17(6), 403-413.

Horton, D., \& Richard, R. (1956). Mass communication and para-social interaction: Observations on intimacy at a distance. Psychiatry, 19(3), 215-229.

House, R. J., Hanges, P. J., Javidan, M., Dorfman, P. W., \& Gupta, V. (2004). Culture, leadership, and organizations: The GLOBE study of 62 societies. Thousand Oaks: Sage Publications.

Huber, F., Meyer, F., \& Schmid, D. A. (2015). Brand love in progress - The interdependence of brand love antecedents in consideration of relationship duration. Journal of Product \& Brand Management, 24(6), 567-579.

Ismail, A. R., \& Spinelli, G. (2012). Effects of brand love, personality and image on word of mouth: The case of fashion brands among young consumers. Journal of Fashion Marketing and Management, 16(4), 386-398.

lyengar, S. (2011). The art of choosing. New York: Twelve.

Joji, A. N., \& Ashwin, J. (2012). Hedonic versus utilitarian values: The relative importance of real and ideal self to brand personality and its influence on emotional brand attachment. The XIMB Journal of Management, 9(2), 77-90.

Jones, T. O., \& Sasser, W. E. (1995). Why satisfied customers defect. Journal of Management in Engineering, 12(6), 1-14.

Kagitcibasi, C. (2005). Autonomy and relatedness in cultural context implications for self and family. Journal of Cross-Cultural Psychology, 36(4), 403-422.

Kahneman, D., Diener, E., \& Schwarz, N. (2003). Well-being: The foundations of hedonic psychology. New York, NY: Russell Sage Foundation.

Kang, A. (2015). Brand love-Moving beyond loyalty: An empirical investigation of perceived brand love of Indian consumer. Arab Economic and Business Journal, 10(2), 90-101.

Karjaluoto, H., Munnukka, J., \& Kiuru, K. (2016). Brand love and positive word of mouth: The moderating effects of experience and price. Journal of Product \& Brand Management, 25(6), 527-537.

Kaufmann, H. R., Loureiro, S. M. C., \& Manarioti, A. (2016). Exploring behavioural branding, brand love and brand co-creation. Journal of Product and Brand Management, 25(6), 1-23.

Keh, H. T., Pang, J., \& Peng, S. (2007). Understanding and measuring brand love. In J. R. Priester (Ed.), Society for consumer psychology conference proceedings (pp. 84-88). Santa Monica.

Langner, T., Bruns, D., Fischer, A., \& Rossiter, J. R. (2016). Falling in love with brands: A dynamic analysis of the trajectories of brand love. Marketing Letters, 27(1), 15-26.

Langner, T., Schmidt, J., \& Fischer, A. (2015). Is it really love? A comparative investigation of the emotional nature of brand and interpersonal love. Psychology and Marketing, 32(6), 624-634.

Laros, F. J. M., \& Steenkamp, J. B. E. M. (2005). Emotions in consumer behavior: A hierarchical approach. Journal of Business Research, 58(10), 1437-1445.

Lee, J. A. (1977). A typology of styles of loving. Personality and Social Psychology Bulletin, 3(2), 173-182.

Levy, S. J. (1985). Dreams, fairy tales, animals, and cars. Psychology \& Marketing, 2(2), 67-81.

Locke, E. A., \& Latham, G. P. (2006). New directions in goal-setting theory. Current Directions in Psychological Science, 15(5), 265-268.

Long-Tolbert, S. J., \& Gammoh, B. S. (2012). In good and bad times: The interpersonal nature of brand love in service relationships. Journal of Services Marketing, 26(6), 391-402. 
Loureiro, S. M. C., Ruediger, K. H., \& Demetris, V. (2012). Brand emotional connection and loyalty. Journal of Brand Management, 20(1), 13-27.

Mano, H., \& Oliver, R. L. (1993). Assessing the dimensionality and structure of the consumption experience: Evaluation, feeling, and satisfaction. Journal of Consumer Research, 20(3), 451.

Masuda, M. (2003). Meta-analyses of love scales: Do various love scales measure the same psychological constructs? Japanese Psychological Research, 45(1), 25-37.

Matzler, K., Pichler, E. A., Füller, J., \& Mooradian, T. A. (2011). Personality, person-Brand fit, and brand community: An investigation of individuals, brands, and brand communities. Journal of Marketing Management, 27(9-10), 874-890.

Matzler, K., Pichler, E. A., \& Hemetsberger, A. (2007). Who is spreading the word? The positive influence of extraversion on consumer passion and brand evangelism. AMA winter Educators' conference proceedings (Vol. 18, pp. 18-25). Chicago, IL: American Marketing Association.

McCrae, R., \& John, O. (1992). An introduction to the five-factor model and its applications. Journal of Personality, 60(2), 175-215.

Moorman, C., Zaltman, G., \& Deshpande, R. (1992). Relationships between providers and users of market research: The dynamics of trust within and between organizations. Journal of Marketing Research, 29(3), 314.

Morgan, R. M., \& Hunt, S. D. (1994). The commitment-trust theory of relationship marketing. Journal of Marketing, 58(3), 20.

Papagiannidis, S., Pantano, E., See-To, E. W. K., \& Bourlakis, M. (2013). Modelling the determinants of a simulated experience in a virtual retail store and users' product purchasing intentions. Journal of Marketing Management, 29(13-14), 1462-1492.

Park, C. W., Eisingerich, A. B., \& Park, J. W. (2013). Attachment-aversion (AA) model of customer-brand relationships. Journal of Consumer Psychology, 23(2), 229-248.

Park, C. W., Maclnnis, D. J., \& Eisingerich, A. B. (2016). Brand admiration: Building a business people love. New Jersey: John Wiley \& Sons.

Park, C. W., Maclnnis, D. J., Priester, J., Eisingerich, A. B., \& lacobucci, D. (2010). Brand attachment and brand attitude strength: Conceptual and empirical differentiation of two critical brand equity drivers. Journal of Marketing, 74(6), 1-17.

Park, C. W., Maclnnis, D. J., \& Priester, J. R. (2006). Beyond attitudes: Attachment and consumer behavior. Seoul National Journal, 12(2), 3-36.

Perse, E. M., \& Rubin, R. B. (1989). Attribution in social and parasocial relationships. Communication Research, 16(1), 59-77.

Pintrich, P. R. (2000). An achievement goal theory perspective on issues in motivation terminology, theory, and research. Contemporary Educational Psychology, 25(1), 92-104.

Rauschnabel, P., Ahuvia, A. C., Ivens, B. S., \& Leischnig, A. (2015). The personality of brand lovers: An examination in fashion branding. Consumer Brand Relationships: Meaning, Measuring, Managing, 1-24. doi:10.1057/9781137427120_6

Rauschnabel, P. A., \& Ahuvia, A. C. (2014). You're so lovable: Anthropomorphism and brand love. Journal of Brand Management, 21(5), 372-395.

Reimann, M., Castaño, R., Zaichkowsky, J., \& Bechara, A. (2012). How we relate to brands: Psychological and neurophysiological insights into consumer-brand relationships. Journal of Consumer Psychology, 22(1), 128-142.

Reimann, M., Maclnnis, D. J., Folkes, V. S., Uhalde, A., \& Pol, G. (2018). Insights into the experience of brand betrayal: From what people say and what the brain reveals. Journal of the Association for Consumer Research, 3(2), 240-254. University of Chicago Press.

Riela, S., Rodriguez, G., Aron, A., Xu, X., \& Acevedo, B. P. (2010). Experiences of falling in love: Investigating culture, ethnicity, gender, and speed. Journal of Social and Personal Relationships, 27(4), 473-493.

Rossiter, J. R. (2012). A new C-OAR-SE-based content-valid and predictively valid measure that distinguishes brand love from brand liking. Marketing Letters, 23(3), 905-916.

Roy, P., Khandeparkar, K., \& Motiani, M. (2016). A lovable personality: The effect of brand personality on brand love. Journal of Brand Management, 23(5), 97-113. 
Rubin, Z. (1970). Measurement of romantic love. Journal of Personality and Social Psychology, 16(2), 265-273.

Sallam, M. A. (2014). The effects of brand image and brand identification on brand love and purchase decision making: The role of WOM. International Business Research, 7, 10.

Sampedro, A. (2017). Brand hate and brand forgiveness - A dynamic analysis. Honors Program Theses. Florida, USA: Rollins College.

Sangrador, J. L., \& Yela, C. (2000). What is beautiful is loved?" Physical attractiveness in love relationships in a representative sample. Social Behavior and Personality: an International Journal, 28(3), 207-218.

Schmid, H., \& Klimmt, C. (2011). A magically nice guy: Parasocial relationships with Harry Potter across different cultures. International Communication Gazette, 73(3), 252-269.

Shimp, T. A., \& Madden, T. J. (1988). Consumer-object relations: A conceptual framework based analogously on Sternberg's triangular theory of love. Advances in Consumer Research, 15(1), 163-168.

Sirgy, M. J., Lee, D. J., Johar, J. S., \& Tidwell, J. (2008). Effect of self-congruity with sponsorship on brand loyalty. Journal of Business Research, 61(10), 1091-1097.

Sternberg, R. J. (1986). A triangular theory of love. Psychological Review, 93(2), 119-135.

Sternberg, R. J. (1997). Construct validation of a triangular love scale. European Journal of Social Psychology, 27(3), 313-335.

Tajfel, H. (1981). Human groups and social categories: Studies in social psychology. Cambridge, UK: Cambridge University Press. doi:10.1017/S0021932000023336

Thomson, M. (2006). Human brands: Investigating antecedents to consumers' strong attachments to celebrities. Journal of Marketing, 70(3), 104-119.

Thomson, M., Maclnnis, D. J., \& Whan Park, C. (2005). The ties that bind: Measuring the strength of consumers' emotional attachments to brands. Journal of Consumer Psychology, 15(1), 77-91.

Vernuccio, M., Pagani, M., Barbarossa, C., \& Pastore, A. (2015). Antecedents of brand love in online network-based communities. A social identity perspective. Journal of Product and Brand Management, 24(7), 706-719.

Vivek, S. (2009). A scale of consumer engagement (Doctor of Philosophy Dissertation). Department of Management \& Marketing, Graduate School-The University of Alabama.

Vlachos, P. A., \& Vrechopoulos, A. P. (2012). Consumer-retailer love and attachment: Antecedents and personality moderators. Journal of Retailing and Consumer Services, 19(2), 218-228.

Voorn, R., Hegner, S., \& Pruyn, A. (2015). Product type and personality in brand relationships. In M. Fetscherin \& T. Heilmann (Eds.), Consumer brand relationship (pp. 83-107). London: Palgrave Macmillan.

Voss, K. E., Spangenberg, E. R., \& Grohmann, B. (2003). Measuring the hedonic and utilitarian dimensions of consumer attitude. Journal of Marketing Research, 40(3), 310-320.

Wallace, E., Buil, I., \& de Chernatony, L. (2014). Consumer engagement with self-expressive brands: Brand love and WOM outcomes. Journal of Product \& Brand Management, 23(1), 33-42.

Wang, Q. (2001). "Did you have fun?": American and Chinese mother-child conversations about shared emotional experiences. Cognitive Development, 16(2), 693-715.

Whang, Y.-O., Allen, J., Zhang, H., Sahoury, N., Kahn, B. E., \& Frances Luce, M. (2004). Falling in love with a product: The structure of a romantic consumer-product relationship. Association for Consumer Research, 31, 316-328.

Yoon, C., Gutchess, A. H., Feinberg, F., \& Polk, T. A. (2006). A functional magnetic resonance imaging study of neural dissociations between brand and person judgments. Journal of Consumer Research, 33(1), 31-40.

Zarantonello, L., Formisano, M., \& Grappi, S. (2016). The relationship between brand love and actual brand performance: Evidence from an international study. International Marketing Review, 33(6), 806-824.

Zarantonello, L., Romani, S., Grappi, S., \& Bagozzi, R. P. (2016). Brand hate. Journal of Product and Brand Management, 25(1), 11-25. 
Table A1 (Appendix)

\section{Brand love scale measurements}

\begin{tabular}{lcc}
\hline Items & Cronbach's & Source \\
\hline $\begin{array}{l}\text { Unidimensional scale for brand love; interpersonal love } \\
\text { theory }\end{array}$ & 0.91 & $\begin{array}{c}\text { Carroll and Ahuvia } \\
\text { (2006) }\end{array}$
\end{tabular}

10 items, 5 points each, Likert-type scale;

This is a wonderful brand.

This brand makes me feel good.

This brand is totally awesome.

I have neutral feelings about this brand. (-)

This brand makes me very happy.

I love this brand!

I have no particular feelings about this brand. (-)

This brand is a pure delight.

I am passionate about this brand.

I'm very attached to this brand.

Multi-dimensional scale for brand love; interpersonal love theory

32 items, 10 points each, Likert-type scale;

There is something almost 'magical' about my relationship with this brand.

There is nothing more important to me than my relationship with this brand

I idealize this brand

Intimacy

I have a warm and comfortable relationship with this brand

I feel emotionally close to this brand

I value this brand greatly in my life

Dream

This brand corresponds to an ideal for me

I dream about that brand since long

This brand is a childhood dream

I dream (or have dreamt) to possess this brand

Pleasure

By buying this brand, I take pleasure

Discovering new products from this brand is a pure pleasure

I take a real pleasure in using this brand

I am always happy to use this brand

Memories

This brand reminds me of someone who is important to me

This brand reminds me of memories, moments of my past

(childhood, adolescence, a meeting, ...)

I associate this brand with some important events of my life

Unicity

This brand is special

This brand is unique

This brand is exclusive and separated from other brands.

Affection

I experience great happiness with this brand.

I feel emotionally close to this brand. 
(Continued).

Items $\quad$ Cronbach's $\quad$ Source

When I am with this brand, we are almost always in the same mood.

I think that this brand and I are quite similar to each other.

There is something almost 'magical' about my relationship with this brand.

I feel tender toward this brand.

Passion

If I could never be with this brand, I would feel miserable.

I find myself thinking about this brand frequently during the day.

Sometimes I feel I can't control my thoughts; they are obsessively on the brand.

If I were separated from this brand for a long time, I would feel intensely lonely.

There is nothing more important to me than my relationship with the brand.

I would feel deep despair if this brand left me

\section{Unidimensional scale for brand love; interpersonal love and parasocial love theory}

15 items (8 items for parasocial love, 7 items for interpersonal love), 5 points each, Likert-type scale;

Interpersonal love:

When I think of this car brand, it is hard for me to say exactly when the friendship turned into love for this brand

In truth, the love I have for this car brand required friendship first

I expect to always be friends with this car brand

The love I have for the car brand is the best kind because it grew out of a long friendship

The friendship with the car brand merged gradually into love over time

The love relationship is really a deep friendship, not a mysterious, mystical emotion

The love relationship is the most satisfying because it developed from a good friendship

Parasocial love:

I feel sorry for this car brand when there is negative news

This car brand makes me feel comfortable, as if I'm with friends

I see this car brand as a natural, down-to-earth person

I'm looking forward to using this car brand

I miss seeing this car brand when it's not available at a rent-a-car agency

This car brand seems to understand the kind of things I want

I find this car brand attractive

If there were a story about this car brand in a newspaper or magazine, I would read it

\section{Multi-dimensional scale for brand love; interpersonal love and consumer experience}

13 items, 7 points each, Likert-type scale;

Fantasies and thoughts

I frequently find myself thinking about this brand
0.72 (US sample)

0.75 (Japanese sample)

0.89 (US sample) $\quad$ Fetscherin (2014)

0.81 (Japanese sample)

0.958 (Fantasies and thoughts)

Zarantonello, Formisano, \& Grappi (2016)

0.952 (Attachment)

0.945 (Self-expression)

0.909 (Pleasure) 
(Continued).

\begin{tabular}{|c|c|c|}
\hline Items & Cronbach's & Source \\
\hline I often fantasize about this brand & 0.925 (Idealization) & \\
\hline \multicolumn{3}{|l|}{ My daydreams often include this brand } \\
\hline \multicolumn{3}{|l|}{ Attachment } \\
\hline \multicolumn{3}{|l|}{ I feel bonded to this brand } \\
\hline \multicolumn{3}{|l|}{ I feel a lot of affection for this brand } \\
\hline \multicolumn{3}{|l|}{ I feel attached to this brand } \\
\hline \multicolumn{3}{|l|}{ Self-expression } \\
\hline \multicolumn{3}{|l|}{ It says something about who I am } \\
\hline \multicolumn{3}{|l|}{ It helps express myself } \\
\hline \multicolumn{3}{|l|}{ This brand says something meaningful } \\
\hline \multicolumn{3}{|l|}{ Pleasure } \\
\hline \multicolumn{3}{|l|}{ This brand gives me great pleasure } \\
\hline \multicolumn{3}{|l|}{ This brand makes me feel good } \\
\hline \multicolumn{3}{|l|}{ Idealization } \\
\hline \multicolumn{3}{|l|}{ This brand represents my ideal... } \\
\hline \multicolumn{3}{|l|}{ This brand is close to perfection } \\
\hline $\begin{array}{l}\text { Multi-dimensional scale for brand love; consumer } \\
\text { experience }\end{array}$ & n.a. (26-item scale) & $\begin{array}{l}\text { Bagozzi, Batra, } \\
\quad \text { \&Ahuvia (2017) }\end{array}$ \\
\hline 26,13 and 6 items, 7 points each, Likert-type scale; & 0.92 (13-item scale) & Ahuvia (2017) \\
\hline To what extent do you feel that... & 0.83 (6-item scale) & \\
\hline
\end{tabular}

Wearing of American Eagle Outfitters says something 'true' and 'deep' about whom you are as a person? a,b

American Eagle Outfitters is an important part of how you see yourself?

To what extent is American Eagle Outfitters able to...

- Make you look like you want to look? a

- Make you feel like you want to feel?

To what extent is American Eagle Outfitters able to...

- Do something that makes your life more meaningful? a

- Contribute something towards making your life worth living?

To what extent do you...

- Find yourself thinking about American Eagle Outfitters? a

- Find that American Eagle Outfitters keeps popping into your head?

To what extent...

- Are you willing to spend a lot of money improving and finetuning a product from American Eagle Outfitters after you buy it? a

- Are you willing to spend a lot of TIME improving and fine-tuning a product from American Eagle Outfitters after you buy it?

Using the products: To what extent do you feel yourself...

- Desiring to wear American Eagle clothing? $a, b$

- Longing to wear American Eagle clothing?

To what extent have you...

- Interacted with American Eagle Outfitters in the past? a

- Been involved with American Eagle Outfitters in the past?

Please express the extent to which...

- You feel there is a natural 'fit' between you and American Eagle Outfitters. $a$

- American Eagle Outfitters seems to fit your own tastes perfectly. 
(Continued).

Items

Cronbach's

Source

Please express the extent to which...

- You feel emotionally connected to American Eagle Outfitters? a, $b$

- You feel you have a 'bond' with American Eagle Outfitters.

To what extent do you feel that American Eagle Outfitters...

- Is fun? a

- Is exciting?

Please express the extent to which you...

- Believe that you will be wearing American Eagle Outfitters for a long time. $a, b$

- Expect that American Eagle Outfitters will be part of your life for a long time to come.

Suppose American Eagle Outfitters were to go out of existence, to what extent would you feel...

- Anxiety $a, b$

- Apprehension

On the following scales, please express your overall feelings and evaluations towards American Eagle Outfitters.

- 7-point negative-positive $a, b$

- 7-point unfavourable-favourable

Note: $a$ : Item for reduced 13-item scale

$b$ : Item for reduced 6 -item scale 